\title{
The Impact of Regulation on Mortgage Risk: Evidence from India
}

\section{Citation}

Campbell, John Y., Tarun Ramadorai, and Benjamin Ranish. 2015. “The Impact of Regulation on Mortgage Risk: Evidence from India.” American Economic Journal: Economic Policy 7, no. 4: 71102. doi: $10.1257 /$ pol.20130220.

\section{Published Version}

10.1257/pol.20130220

\section{Permanent link}

http://nrs.harvard.edu/urn-3:HUL.InstRepos:34331451

\section{Terms of Use}

This article was downloaded from Harvard University's DASH repository, and is made available under the terms and conditions applicable to Open Access Policy Articles, as set forth at http:// nrs.harvard.edu/urn-3:HUL.InstRepos:dash.current.terms-of-use\#OAP

\section{Share Your Story}

The Harvard community has made this article openly available.

Please share how this access benefits you. Submit a story.

\section{Accessibility}




\title{
The Impact of Regulation on Mortgage Risk: Evidence from India*
}

\author{
John Y. Campbell, Tarun Ramadorai, and Benjamin Ranish ${ }^{\dagger}$
}

This version: September 2014

First draft: September 2012

\begin{abstract}
We employ loan-level data on over a million loans disbursed in India between 1995 and 2010 to understand how fast-changing regulation impacted mortgage lending and risk. Our paper uses changes in regulatory treatment discontinuities associated with loan size and leverage to detect regulation-induced loan delinquencies. We also find that an acceleration in the classification of assets as non-performing resulted in substantially lower delinquency probabilities and losses given delinquency.
\end{abstract}

\footnotetext{
*We gratefully acknowledge an Indian mortgage provider for providing us with the data, and many employees of the Indian mortgage provider, Santosh Anagol, Amit Bubna, Jishnu Das, Jennifer Huang, Ajay Shah, S. Sridhar, Usha Thorat, R. V. Verma, Vikrant Vig, Alan Auerbach (the editor) and two anonymous referees for useful comments and discussions. We thank seminar participants at the Econometric Society/European Economics Association Malaga Conference, the NBER Household Finance Summer Institute, IIM Bangalore, the World Bank, the Oxford-Man Institute of Quantitative Finance, Saïd Business School, the HKUST Household Finance Symposium, the NUS-IRES Real Estate Symposium, the NHB-CAFRAL Conference, and the NIPFP-DEA Conference on International Capital Flows for comments, the International Growth Centre and the Sloan Foundation for financial support, and Vimal Balasubramaniam, Gaurav Kankanhalli, and Kevin Wang for able research assistance. An earlier version of this paper was circulated under the title "How Do Regulators Influence Mortgage Risks? Evidence from an Emerging Market."

${ }^{\dagger}$ Campbell: Department of Economics, Littauer Center, Harvard University, Cambridge MA 02138, USA, and NBER. Email john_campbell@harvard.edu. Ramadorai: Saïd Business School, Oxford-Man Institute of Quantitative Finance, University of Oxford, Park End Street, Oxford OX1 1HP, UK, and CEPR. Email tarun.ramadorai@sbs.ox.ac.uk. Ranish: Board of Governors of the Federal Reserve System, 1850 K Street NW, Mailstop 1800, Washington, DC 20006. Email ben.ranish@frb.gov. The views in this paper are solely the responsibility of the authors and should not be interpreted as those of the Board of Governors of the Federal Reserve System, or of other members of their staff.
} 


\section{Introduction}

How does mortgage regulation influence the structure and performance of housing finance? This paper answers the question with administrative data on over 1.2 million loans originated by an Indian mortgage provider. We relate loan pricing and delinquency rates to the changing details of Indian mortgage regulation.

One way to understand how government involvement affects mortgage markets is to collect evidence from cross-country data, as in International Monetary Fund (2011). This approach is complicated by the difficult to measure and potentially unobservable factors which may affect household mortgage choice across countries. For example, historical experiences with interest rate and inflation volatility can have long-lasting effects because consumers can be slow to adopt new financial instruments (Campbell 2013).

A promising alternative is to trace the effects of changing mortgage regulation over time within a single country, but this approach is difficult to implement in developed countries, as they tend to have fairly stable systems of financial regulation. This creates few opportunities to observe the effects of sharp regulatory changes. Slow changes, such as those that occurred in the US during the early and mid-2000s, may well be important but it is hard to show this convincingly. For this reason academic writers and public policy commentators have reached little consensus on the degree to which regulation, rather than other factors, caused the US mortgage credit boom. ${ }^{1}$

Mortgages are rapidly becoming important financial instruments in emerging markets. Here, financial regulation is at least as intrusive and much less stable. In addition, longlasting historical influences are likely to be less important in emerging markets because their rapid growth and financial evolution reduce consumer inertia. For this reason, emerging markets are ideal laboratories in which to examine the effects of mortgage regulation.

Our study focuses on the mortgage market in India. The provision of housing finance in

\footnotetext{
${ }^{1}$ A range of views can be found in Acharya, Richardson, van Nieuwerburgh, and White (2011), Baily (2011), Ellis (2008), International Monetary Fund (2011), and US Treasury and Department of Housing and Urban Development (2011), among other sources. Dahl, Evanoff, and Spivey (2000), Kroszner (2008), Avery and Brevoort (2011), and Agarwal, Benmelech, Bergman, and Seru (2012) debate the importance of the Community Reinvestment Act (CRA) in encouraging risky lending to lower-income borrowers.
} 
India is evolving particularly rapidly (Tiwari and Debata 2008, Verma 2012). Regulatory norms have changed frequently, albeit with a continuing emphasis on funding housing for lowincome households. The country has been studied extensively by the economics profession, mainly to analyze issues of poverty and development (see for example Besley and Burgess 2000 and Banerjee, Cole, Duflo, and Linden 2007), or the impact of the Byzantine system of laws and regulations on industrial organization and firm output (see for example Aghion, Burgess, Redding, and Zilibotti 2008 and von Lilienfeld-Toal, Mookherjee, and Visaria 2012). India underwent an economic liberalization in the early 1990s and subsequently experienced rapid economic growth that accelerated further in the 2000s. During this time the financial sector has become much larger and more sophisticated, but remains highly regulated, with a significantly nationalized banking sector. Recently, authors such as Anagol and Kim (2012) have begun to study Indian financial regulation and its impacts on fast-changing Indian capital markets.

Rich microeconomic data are necessary to convincingly answer questions about loan structure and performance, and we are fortunate to have access to loan-level administrative data from an Indian mortgage provider. ${ }^{2}$ While our study is limited by its focus on data from a single mortgage provider, the large number of loans that we analyze, the broad geographical distribution of the loans, and the quarter-century over which the data are available provide some confidence in the broader validity of our results. In addition we note that the Indian mortgage lending market was highly concentrated early in our sample period, which implies that data from a single provider can represent a meaningful fraction of total Indian mortgage lending. ${ }^{3}$

Our ability to use micro-data is particularly important for our study, because pure timeseries variation in mortgage risk, even if correlated with changing regulation, may also be

\footnotetext{
${ }^{2}$ Some recent mortgage studies using US microeconomic data include Adelino, Gerardi, and Willen (2013), Agarwal, Amromin, Ben-David, Chomsisengphet, and Evanoff (2011), Amromin, Huang, Sialm, and Zhong (2011), Bhutta, Dokko, and Shan (2010), Demyanyk and van Hemert (2011), Foote, Gerardi, Goette, and Willen (2010), Johnson and Li (2011), Keys, Mukherjee, Seru, and Vig (2010), Melzer (2011), Mian and Sufi (2009), and Piskorski, Seru, and Vig (2011).

${ }^{3}$ More recently, however, there has been increasing competition between mortgage lenders, a fact which may have contributed to rapidly increasing house prices since 2002.
} 
explained by the changing state of the macroeconomy. Instead, our difference-in-difference approach searches for effects of regulatory changes on loan delinquencies, by focusing on changes in regulatory treatment discontinuities in loan characteristics such as loan size and loan-to-value (LTV) ratios.

Our approach yields three main findings on the relation between regulation and mortgage risk. First, throughout the period of study, small and micro loans are particularly favoured by the Indian regulatory environment. We show that implicit subsidies to smaller loans qualifying as "priority sector lending" (PSL) show up as discontinuities in both the volume of lending and delinquency rates at the qualifying threshold-with loan delinquency rates being substantially higher just under the qualifying threshold than just above. These discontinuities appear even though we control for the initial interest rates charged by the mortgage lender, implying that the lender is willing to accept a higher delinquency rate for a similar loan interest rate (or equivalently, is willing to charge a lower interest rate for a comparable delinquency rate) when a loan is PSL-qualifying. The nominal PSL-qualifying loan size threshold was reset only four times during our quarter-century sample, despite rapidly rising nominal home prices over the period. We show that the discontinuities in loan delinquency rates around the PSL thresholds are larger just prior to threshold resets - times at which the PSL requirement should bind most tightly.

Our second finding concerns the impact of variation in mortgage lender capital requirements, which in India takes the form of changes in risk weights on mortgages with different LTV ratios. Over the period that we study, the risk weights for mortgages disbursed at LTV ratios of $75 \%$ or below have varied from between $50 \%$ and $100 \%$ of the risk weights for loans with higher LTV ratios. We find that when risk weights on mortgages disbursed at LTV ratios at and just under $75 \%$ are relatively lower, the subsequent delinquency rates on these mortgages are relatively higher, after accounting for interest rates at loan issuance. Furthermore, the size of this discontinuity in delinquency rates tracks the size of the risk weight advantage given to relatively lower-leverage loans. Once again this implies that the lender is willing to accept a higher delinquency rate for a similar loan interest rate (or equivalently, is willing to charge a lower interest rate for a comparable delinquency rate) when a mortgage 
loan receives a more favorable risk weight. These findings confirm predictions that changes in risk weights do impact bank lending activity, and ultimately loan delinquencies (see, for example, Calem and Follain 2007, and Balasubramanyan and Jacques 2011).

Our third finding relates to a regulatory reclassification of "non-performing assets" (NPAs) from loans that are 180 days delinquent on contracted payments to those that are only 90 days delinquent on payments. Since capital provisioning requirements against delinquencies are tied to this classification, this change incentivizes the mortgage provider to monitor loans earlier, and potentially to intensify loan screening. We obtain a random subsample of loans from the lender for which we are given a complete time series of payment histories, and we show that this regulatory reclassification appears to result in greater effort expended on monitoring delinquencies approaching the 90-day mark. Specifically, we find that the lender's likelihood of experiencing both short-term (90-day) delinquencies and longer-term defaults falls substantially. We find that the impact of this change on long-term defaults is even larger than that arising from a 2002 legal change in the ability of mortgage providers to more easily repossess or restructure non-performing assets. Finally, we also find evidence that there is more rigorous screening of loan quality prior to issuance following this redefinition of NPAs; mortgage cohorts disbursed shortly after the change experience fewer and less costly delinquencies than those disbursed shortly before.

This evidence from India contributes to the debate on whether incentives for lending to lower-income borrowers in other countries, such as those created by the U.S. Community Reinvestment Act (CRA), have affected loan delinquencies (see, for example, Canner and Passmore 1997, Dahl, Evanoff, and Spivey 2000, Kroszner 2008, Avery and Brevoort, 2011, and Agarwal, Benmelech, Bergman, and Seru 2012). ${ }^{4}$ Our results also relate to evidence that mortgage credit expansion in the U.S., particularly in sub-prime zipcodes, contributed to the rise in mortgage delinquencies and the broader economic downturn after 2007 (Mian and Sufi 2009, Demyanyk and van Hemert 2011). Finally, our results are consistent with the

\footnotetext{
${ }^{4}$ Regulatory loan size thresholds have also been studied in other contexts. For example, DeFusco and Paciorek (2014) and Adelino, Schoar, and Severino (2014) use the conforming loan limit in the U.S. to measure interest rate elasticity, and the impact of the implied lending subsidies on home prices, respectively.
} 
finding of Keys, Mukherjee, Seru, and Vig (2011) that U.S. regulatory norms have affected mortgage screening.

It is worth mentioning two caveats about our findings. First, our results do not allow us to make claims about the potential welfare improvements associated with changes in regulatory policy. There may be substantial public benefits associated with programs intended to expand credit to lower-income and potentially less creditworthy borrowers, and we do not measure these benefits in our paper.

Nevertheless, we believe that paying attention to the details of policy design may yield significant benefits. Our results suggest that the current form of the PSL policy may be sub-optimal, with substantial increases in delinquencies in periods when nominal thresholds remain constant while house prices are rising, and corresponding reductions in these delinquencies when nominal thresholds are (infrequently) adjusted. A better-designed policy might simply index the PSL-qualifying nominal threshold to a commonly available house price index to avoid this "lumpy adjustment" of delinquency rates. This would be helpful to allow lenders to better manage their balance sheets, and might reduce the social costs that can arise from spikes in default rates (Campbell, Giglio, and Pathak 2011).

Second, while we do measure significant benefits from early action on potentially delinquent loans, we are unable to measure the costs of improving screening and monitoring, which include both direct costs to lenders and the impact of screening on access to credit. While this makes it difficult for us to assess the net welfare impact of responding more quickly to potential delinquencies, more work in this area might be worthwhile given the large benefits that we identify.

The organization of the paper is as follows. Section 2 describes the Indian macroeconomic environment and the Indian system of mortgage regulation during the quarter century since 1985, together with the mortgage data we employ. Further details of Indian mortgage regulation are provided in an online regulatory appendix (Campbell, Ramadorai, and Balasubramaniam 2014). Section 3 introduces our model of mortgage delinquencies, which we use to explore the effects of regulation - specifically, quotas on priority sector lending and risk weights on lower loan-value mortgages - on the relative delinquency rates of different types 
of loans. Section 4 discusses the change in the regulatory classification of non-performing assets in 2004 and its consequences for observed delinquency and repayment patterns. Section 5 concludes. Additional empirical evidence on the Indian mortgage market is reported in an online empirical appendix (Campbell, Ramadorai, and Ranish 2014).

\section{The Macroeconomic and Regulatory Environment}

\subsection{Macroeconomic Trends}

Table 1 summarizes the history of several important Indian macroeconomic variables over the period 1985-2010, including annual real GDP growth, CPI inflation, and government bond yields. Regulatory and macroeconomic reform in the early 1990s was followed by growth in the $4-8 \%$ range until the early 2000 s, when growth accelerated above $8 \%$, briefly slowed again only by the global financial crisis in 2008. Meanwhile inflation was high and volatile during the 1990s, with volatility particularly elevated around the reform period and in 1998-99. A period of more stable inflation followed in the 2000s, but inflation accelerated at the very end of our sample period.

Indian government bond yields over the same period were correspondingly volatile. The 1-year yield declined from double-digit levels in the mid-1990s, with a brief reversal in the late 1990s. After a low of about $5 \%$ in the early 2000s, the 1-year yield spiked up to almost $8 \%$ in 2008, again related to concerns about inflation. The 10-year yield moved more smoothly but also declined substantially from the mid-1990s until the early 2000s.

Figure 1 plots real house price indexes, both for India as a whole and for five broad regions. The real rate of house price appreciation for the country as a whole is also reported in Table 1. We compute these indexes using the mortgage provider's own property cost data, but data from the National Housing Bank (NHB), which are available for only part of the sample period, show similar patterns. Indian house prices were relatively stable until the early 2000s and then began to increase rapidly, particularly in the south of the country. The southern index peaked in 2008 while some other regions peaked in 2009. Thus India 
took part in the worldwide housing boom despite many differences in other aspects of its macroeconomic performance.

These house price movements are important for our study because they interact with government policies favoring smaller loans. As house prices increase and the priority sector qualifying threshold remains constant, fewer loans naturally qualify for lenders' priority sector lending quotas, creating time variation in the tightness of regulatory constraints on mortgage lending.

\subsection{The Regulatory Environment}

Mortgages in India are originated by two types of financial institutions, banks and housing finance companies (HFCs). Banks are regulated by the Reserve Bank of India (RBI), while housing finance companies are regulated by the National Housing Bank (NHB), but most regulations apply in fairly similar form to the two types of institution. This fact is important for our study, as we are unable to publicly identify whether our mortgage provider is a bank or an HFC.

Figure 2 summarizes the details of mortgage regulation in India. The top half of the figure shows regulations that applied to banks, and the bottom half shows regulations that applied to HFCs. The regulations that remained constant throughout the period are listed in Roman font, whereas the ones that changed over the period are in italic font. In light of the significant changes that took place from 2001 to 2002, we separate the timeline into the "first period," i.e. prior to March 2001, and the "second period" which extends from April 2001 until the end of 2010. In the middle of the figure, we summarize subsidy schemes for micro-lending with the bars accompanying these schemes identifying their start and end dates relative to the timeline.

Regulations can be divided into two types: those that restrict the funding of mortgage lending in general, and those that incentivize lending to certain borrowers. Until 2001, mortgage funding was regulated in a fairly traditional manner, using leverage restrictions on banks and HFCs, and interest-rate ceilings on deposit-taking HFCs. From 2002 onwards, 
these measures were augmented by capital requirements against risk-weighted assets following the internationally standard Basel II framework. The RBI and NHB distinguished small and very large loans, and loan-to-value (LTV) ratios above and below 75\%, and set different risk weights for these different categories. Figure 3 shows the difference in risk weights on more and less leveraged loans originated by banks (dotted line) and HFCs (dashed line) over time. The regulatory preference for less leveraged loans was greatest during the period 2002 to 2004 .

It is important to note here that a majority of Indian mortgage providers chose to interpret these LTV regulations as applying to loan-to-cost (LTC) ratios, where transactions costs such as stamp duty land tax and registration and documentation charges were added into the property value at the time of purchase. This practice was so widely prevalent that the RBI issued a circular in February 2012, fourteen months following the end of our sample period, to discourage this practice (see the online regulatory appendix for details). We are provided with LTC data, and we use the terms LTC and LTV interchangeably in our analysis below.

Another noteworthy change in the regulatory environment is highlighted on the timeline in Figure 2, and occurred on March 31, 2004 for banks, and one year later, i.e., March 31, 2005 for HFCs. At this time the RBI reclassified an asset as a "non-performing asset" (or NPA) if payments (on interest or principal) remained overdue for a period of ninety days or more, from the previous 180 day period allowed before assets were so classified. One important implication of the classification of an asset as an NPA is that it incurs provisioning requirements, meaning that the capital available to a mortgage lender holding such an asset reduces as the lender is required to hold precautionary capital to cover expected losses.

Related to this NPA reclassification, an important law which came into force somewhat earlier (in July 2002), was the Securitization and Reconstruction of Financial Assets and Enforcement of Security Interest (SARFAESI) Act. This law enabled the easier recovery of NPAs via securitization, reconstruction, or direct repossession, bypassing the need for secured creditors to seek permission from debt recovery tribunals (see von Lilienfeld-Toal, Mookherjee, and Visaria 2012 on the impacts of the establishment of these tribunals in 1993, 
and Vig 2013 on the impacts of SARFAESI on Indian firms). In our analysis, we separately evaluate the impact of these two changes, namely the reclassification of NPAs in 2004, and the introduction of SARFAESI in 2002, on delinquency costs experienced by the mortgage provider.

Lending to small borrowers is an important political goal in India. Banks are subject to a quantity target for priority sector lending (PSL), which includes loans to agriculture, small businesses, export credit, affirmative action lending, educational loans, and - of particular interest to us - mortgages for low-cost housing. The PSL target is $40 \%$ of net bank credit for domestic banks (32\% for foreign banks), and there is a severe financial penalty for failure to meet the target, namely, compulsory lending to rural agriculture at a haircut to the repo rate. This regulation does not directly apply to HFCs, but bank lending to an HFC qualifies for the PSL target to the extent that the HFC makes mortgage loans that qualify, i.e., are below the nominal PSL threshold shown in Figure 3. The overall effect of the PSL system is to provide an incentive, directly for banks, and indirectly for HFCs, to originate small mortgages that (typically) finance low-cost housing purchases.

In addition to the PSL system, other schemes have been introduced at various times to subsidize new or refinanced micro-lending - i.e., loans of sizes well below the PSL-qualifying threshold. The mid-section of Figure 2 shows the various schemes that were in place during our sample period to incentivize mortgage lending in very small loan sizes. These schemes apply to both banks and HFCs. Most recently, interest rate subventions have been put in place for the first year of repayments on small loans, payments that are passed through to the borrower in the form of a reduced interest rate, for housing loans up to a maximum size. Special subsidy and refinancing schemes in place for very small rural loans (the Golden Jubilee Rural Housing Finance Scheme or GJRHFS, and the Indira Awaas Yojana) and for borrowers qualifying for affirmative action (the Differential Rate of Interest scheme) are also shown in the figure, over the period for which they applied. Taken together, these schemes increase the subsidy for tiny loans over and above the standard subsidy to PSL-qualifying loans.

The online regulatory appendix, Campbell, Ramadorai, and Balasubramaniam (2014), 
provides further details about the regulatory system, and serves as a comprehensive guide to Indian mortgage regulation over the period of our study.

\subsection{Evolution of the Mortgage Market}

Both macroeconomic and regulatory forces have contributed to rapid change in the Indian mortgage market. Table 2 illustrates the changes in three relevant characteristics of mortgages issued by our lender: the shares of variable-rate mortgages, and two categories of loans relatively favored by the regulatory environment, namely, small PSL-qualifying loans, and mortgages with loan-cost ratios at or below $75 \%$.

The first two columns of Table 2 report the variable-rate share in the number and value of mortgages disbursed. There has been a dramatic shift in the Indian mortgage system away from fixed-rate and towards variable-rate mortgages, with one brief interruption in 2004. Our lender issued very few fixed-rate mortgages after 2007. During the period of transition through 2002, variable-rate mortgages had somewhat larger principal amounts on average than fixed-rate mortgages, as shown by their higher share of value in the second column of the table.

The next two columns of the table report the share of mortgages that are below the PSL threshold, separately for variable-rate and fixed-rate mortgages. The share below the PSL threshold peaks in 2000 for both fixed- and variable-rate mortgages, and then declines precipitously during the 2000s. The PSL-qualifying share is somewhat higher for fixed-rate mortgages, reflecting their smaller average size.

The final two columns of the table report the share of mortgages with loan-cost ratios at or below 75\%, again separately for variable-rate and fixed-rate mortgages. This share trends downwards, particularly rapidly in the early 2000s (for variable-rate mortgages) and the late 1990s (for fixed-rate mortgages). Both these trends are driven in part by the increase in house prices during the mid-1990s and mid-2000s, shown earlier in Table 1 and Figure 1.

Table 3 presents more details on cohorts of loans issued in each year. Panel A reports equally weighted cross-sectional cohort means of mortgage terms and delinquency rates. 
Initial interest rates on variable-rate and fixed-rate mortgages track one another very closely until 2002, and are both close to the Indian prime rate shown in Table 1, despite some variation in the spread between long-term and short-term government yields. In the period 2003-06, the variable mortgage rate is well above the fixed rate and has an unusually high spread over the 1-year bond yield, a feature shared with the Indian prime rate. This period has a generally high market share for variable mortgages, but does include an episode in 2004 when our mortgage lender shifted back towards fixed mortgage issuance. Variable mortgage rates decline after 2008, a period where our lender made few fixed-rate mortgages.

Panel A also summarizes cohort means of loan maturity, loan-cost ratios, and loanincome ratios. The previously discussed increase in loan-cost ratios is visible here too, but loan maturity and loan-income ratios are much more stable. This pattern contrasts with mortgage trends during the 2000s in the US, where loan-income ratios increased more rapidly than loan-value ratios (Campbell and Cocco 2014).

The right-hand columns report the cohort 90-day delinquency rate, the annual probability that an outstanding and not-yet-delinquent loan experiences a 90-day delinquency, calculated separately for each disbursal-year cohort and calendar year, and then averaged over calendar years for each cohort. The early 2000s appear unusual in the sense that the cohort default rate for mortgages disbursed in these years is high relative to the other cohorts in the sample period, despite loan characteristics such as loan-cost and loan-income ratios not changing much on average. The 2004 fixed-rate cohort, however, appears to have a significantly lower default rate.

The top plot of Figure 4 summarizes Indian mortgage delinquency history in a simpler way. It plots the overall delinquency rate (the fraction of all outstanding mortgages, regardless of the date of issue, that are 90 days past due), seasonally adjusted using a regression on monthly dummies, for both fixed-rate mortgages (solid line) and variable-rate mortgages (dashed line). The main feature of this figure is the large spike in delinquencies in 2002-03, particularly for fixed-rate mortgages. Delinquencies decline to quite low levels by 2005, and remain low to the end of our sample period despite the weak housing market in 2009-10.

Since Indian mortgage rates declined steadily from the mid-1990s to the mid-2000s, it 
is not surprising that fixed-rate mortgages had higher delinquency rates than variable-rate mortgages during this period. As Campbell and Cocco (2014) emphasize, variable-rate borrowers benefit directly from declining rates while fixed-rate borrowers only benefit if they can refinance their mortgages, a process that requires alert, creditworthy borrowers with positive home equity. However this does not explain why delinquency rates increased for both types of borrowers in the early 2000s.

The bottom plot of Figure 4 addresses this question using two different measures of macroeconomic conditions: real GDP growth, and the average real rate of growth in corporate sales, firm fixed assets, and firm net worth estimated from the population of Indian firms available in the Prowess database. ${ }^{5}$ Both measures are standardized to have a zero mean and unit standard deviation during the sample period. Figure 4 shows that the elevated delinquency rates in the early 2000s were preceded by an extended period of below-average economic conditions.

Panel B of Table 3 shows the cross-sectional standard deviations of loan characteristics and initial interest rates. In the early 2000s there is a large spike in the cross-sectional dispersion of variable mortgage rates. This spike coincides with the period of increased delinquencies documented earlier, and may reflect increased efforts by our mortgage lender to distinguish among borrowers by estimating their default risk and setting mortgage rates accordingly. For fixed mortgage rates, while the same pattern is not evident in the crosssectional dispersion of initial interest rates, there does seem to be an increase in the early 2000s in the cross-sectional dispersion of loan-cost ratios, which reduces again in 2004 .

In the remainder of this paper, we conduct a more detailed exploration of the relation between mortgage regulation and the movements in mortgage delinquencies reported in Table 3 and illustrated in Figure 4.

\footnotetext{
${ }^{5}$ This database comprises the population of listed and large unlisted Indian firms, and is considered to be the main source of information on Indian corporates (see, for example, von Lilienfeld-Toal, Mookherjee, and Visaria, 2012).
} 


\section{Regulation and Delinquencies}

We use a regression discontinuity approach to measure the impact of regulation on delinquencies. Specifically, we measure differences in delinquency rates between loans close to, but on opposite sides of regulatory thresholds.

Our goal is to understand the impacts of changes in the regulatory regime rather than the pure static impacts of regulation, which are harder to convincingly identify. For this reason we focus on regulation-induced discontinuities during small windows of time around dates when regulatory thresholds are altered, considering only these specific time periods and loan sizes near regulatory thresholds. We estimate specifications of the form:

$$
\operatorname{Pr}\left[\delta_{i, t}\right]=Z_{t-1} \exp \left(\alpha_{c}+\beta r_{i}+\tau^{\prime} D_{i}\right)+e_{i, t}
$$

In equation (1), $\delta_{i, t}$ is an indicator for an observed delinquency in loan $i$ at time $t ;{ }^{6} r_{i}$ is the at-issuance interest rate on loan $i$; and $\alpha_{c}$ are cohort fixed effects, estimated using dummies constructed according to loan origination dates. In the model, macroeconomic shocks $Z_{t-1}$ affect loan delinquency rates in a multiplicative fashion. $D_{i}$ is a vector of dummy variables used to capture discontinuities in delinquency rates associated with regulatory treatments, and constructed so that only one element of the vector is nonzero for each mortgage $i$. The vector $\tau$ is a vector of coefficients on these dummy variables. We discuss the construction of the dummy variables at length in the subsections below, as they are the primary focus of our analysis.

Several points should be noted about the specification of equation (1) and our estimation strategy.

First, we condition on the interest rate at issuance to ensure that the coefficients $\tau$ capture delinquencies in excess of those priced in by the lender when accounting for the normal risk of the loan. If we did not do this, we might find no variation in the delinquency rate around the regulatory threshold simply because the lender reduces rates to attract loans favored by

\footnotetext{
${ }^{6}$ We follow the regulatory guidelines on the recognition of delinquencies here, defining delinquencies at the 180-day arrears mark prior to the change in this regulation, and at the 90-day arrears mark subsequently.
} 
regulation, accepting a lower rate but not a higher delinquency rate on such loans. Or, we might find no variation in the interest rate around the regulatory threshold if the lender keeps rates fixed but offers loans to riskier borrowers if they are favored by regulation. In both these cases our method will correctly detect a regulatory effect on delinquencies after controlling for the interest rate at issuance.

Second, we allow for the $Z_{t-1}$ to be different for fixed and variable rate mortgages, to account for the possibility that macroeconomic circumstances affect these two types of loans differently. The subscript $t-1$ indicates that macroeconomic shocks are defined so as to impact delinquencies with a one year lag.

Third, we estimate (1) as a Cox (1972) proportional hazard model, where the macroeconomic shocks $Z$ serve as the baseline hazard rates. As a robustness check, we also re-estimate a version of the model which is linear in covariates using non-linear least squares, as well as estimating a version which is linear with year and interest-rate-type fixed effects by ordinary least squares. ${ }^{7}$ These results are reported in the online appendix.

Fourth, we use a $2 \%$ window around the regulatory threshold and a six-month time window around the time of a change in the threshold as our baseline bandwidth values to balance concerns of sample size attenuation with a smaller bandwidth, and blunting of the discontinuity with a larger one. We check the robustness of our results to variation in the size of these windows.

Fifth, for each model, we compute standard errors from a cross-sectional correlation consistent bootstrap procedure, in which we draw yearly cross-sections of data with replacement, and assemble a simulated dataset for each of 500 bootstrap draws. These standard errors tend to be quite large since our time series contains relatively few episodes of alteration in regulatory thresholds, and cross-sectional observations are subject to correlated shocks.

Finally, in Table A.1 in the online appendix, we provide estimates from a simple model relating delinquencies on loans to borrower and loan characteristic controls, to provide more general insights into the predictors of Indian mortgage delinquency.

\footnotetext{
${ }^{7}$ To avoid multicollinearity, we exclude one of the cohort dummies, and further need to exclude one each of the year and interest rate type dummies in the OLS estimation of this model.
} 
In the following two subsections, we describe how we construct the dummy variables on which we estimate coefficients $\tau$ in order to measure the impact of PSL and risk-weight regulation, and discuss the corresponding results.

\subsection{Regulation and Delinquencies: PSL Thresholds}

Our first exercise is to understand the impact of infrequent adjustment of PSL-qualifying nominal threshold amounts on loan delinquencies. We begin by assessing the relative delinquency rates on loans just below and just above the PSL threshold, which are disbursed at times just before (denoted by the subscript old) and just after (denoted by the subscript new) dates at which the nominal value of the PSL threshold is reset. Thus, to assess the impacts of the nominal PSL threshold resets on the delinquency rates of loans we model $\tau^{\prime} D_{i}$ as:

$$
\begin{aligned}
\tau^{\prime} D_{i} & =\tau_{\text {old,below }} D_{i, \text { old,below }}+\tau_{\text {old,above }} D_{i, \text { old,above }} \\
& +\tau_{\text {new }, \text { below }} D_{i, \text { new }, \text { below }}+\tau_{\text {new }, \text { above }} D_{i, \text { new }, \text { above }}
\end{aligned}
$$

where $D_{i, \text { old,below }}$ is a dummy with the value of one for all loans issued just before the nominal PSL threshold reset in sizes below the PSL threshold, and zero otherwise; $D_{i, \text { old,above }}$ is a dummy for loans issued just before the nominal PSL threshold reset in sizes above the PSL threshold; $D_{i, \text { new, below }}$ is a dummy for loans issued just after the nominal PSL threshold reset in sizes below the PSL threshold; and finally $D_{i, \text { old,above }}$ is a dummy for loans issued just after the nominal PSL threshold reset in sizes above the PSL threshold. The threshold that is relevant for the "old" dummy variables is the one that prevails before the reset, while the threshold that is relevant for the "new" dummy variables is the one that prevails after the reset.

As nominal house prices increase, and the nominal value of the PSL threshold is not adjusted, finding high-quality PSL-qualifying loans becomes more difficult for lenders, who must sacrifice loan quality to meet PSL targets. When the nominal PSL threshold is reset, 
the regulatory constraint becomes looser, allowing the lender to be more discriminating when selecting PSL-qualifying loans. Indeed, we allow for the possibility that the threshold reset is sufficiently large to eliminate the discontinuity, resulting in a weak inequality for the new threshold. Stated in terms of the regression parameters, this implies that we should find:

$$
\tau_{\text {old,below }}-\tau_{\text {old,above }}>\tau_{\text {new,below }}-\tau_{\text {new,above }} \geq 0
$$

We test both that $\tau_{\text {old,below }}-\tau_{\text {old,above }}>0$ and that $\tau_{\text {new,below }}-\tau_{\text {new,above }} \geq 0$, and most importantly that $\left(\tau_{\text {old,below }}-\tau_{\text {old,above }}\right)-\left(\tau_{\text {new,below }}-\tau_{\text {new,above }}\right)>0$. The last test is a difference-in-difference prediction using a small window around threshold resets, and close to the PSL-qualifying threshold.

\section{Loan growth around PSL threshold changes}

Before proceeding to our estimates from the delinquency models, we confirm that our lender's loan disbursal activity changes around the time of PSL threshold revisions in a manner consistent with the PSL regulatory norm being a binding constraint. To illustrate our reasoning here, consider the lender's willingness to make loans of two specific sizes: Rs. 298,000, and Rs. 302,000, just before and just after October 22, 1997, on which date the nominal PSL threshold was revised from Rs. 300,000 to Rs. 500,000.

Prior to October 22, 1997, the Rs. 302,000 loan would not qualify for PSL status. As such, this loan would make it more difficult for a financial institution to meet its overall PSL norm target (for a bank), or reduce the extent to which an HFC can borrow at favorable rates from banks to help them satisfy their priority sector lending goal indirectly. In contrast, the Rs. 298,000 loan counted as PSL-qualifying throughout the short period surrounding October 22, 1997. Provided that the PSL regulation was indeed binding, our lender would have been relatively less willing to sanction Rs. 302,000 loans than Rs. 298,000 loans prior to the date of the change in regulation, and relatively indifferent between the two loan sizes following the increase in the PSL threshold to Rs. 500,000.

As a result, we might expect the volume of Rs. 302,000 loans to grow more quickly 
than that of Rs. 298,000 loans in the time period surrounding the increase in the nominal threshold on October 22, 1997. More generally, in the presence of binding PSL regulation, we might expect the growth rate of loans of size just above the old PSL threshold $\left(g_{\text {old,above }}\right)$ to exceed the growth rate of loans of size just below the old PSL threshold $\left(g_{\text {old,below }}\right)$. Note that this is the exact loan volume analogue to our reasoning about delinquencies in equation (3).

Row [i] of Table 4 shows the results of this test applied to our data, in which the baseline specification uses loan amounts two percent above and below the old PSL-qualifying threshold as the bandwidth. The table also checks robustness to varying the bandwidth from 1.5 percent to three percent. Across these choices, the table shows that the growth rate of lending just above the old constraint is very roughly $100 \%$ greater than lending just below, although standard errors are large due to the limited number of nominal PSL-threshold resets that we observe in the data.

The argument presented above works similarly for loans around the size of the new PSL threshold, with loans of Rs. 498,000 becoming advantaged relative to loans of Rs. 502,000 after the threshold is revised to Rs. 500,000. Thus we should expect the growth rate of loans of size just below the new PSL threshold $\left(g_{\text {new,below }}\right)$ to exceed the growth rate of loans of size just above the new PSL threshold $\left(g_{\text {new, above }}\right)$.Rows [ii] and [iii] of Table 4 are consistent with this reasoning, showing a slightly greater growth rate of lending activity just below the new PSL threshold. The smaller magnitudes here can be attributed to a smaller relative incentive across these loan sizes immediately following upward adjustment of the PSL-qualifying threshold - as the upward adjustment relaxes the PSL constraint.

In aggregate, at large Indian public-sector banks, priority sector lending has fluctuated between $36 \%$ and $44 \%$ of credit outstanding over the past 14 years, close to the PSL norm of 40\%. Data for private-sector banks are not readily available, but presumably the constraint is even more tightly binding for such institutions. Our micro-evidence complements these aggregate statistics and suggests that the PSL constraint has often been binding, leading to greater priority sector lending than would otherwise have occurred. 


\section{Delinquencies around PSL threshold changes}

As a first step, Figure 5 plots the simple average of delinquency rates in a window of six months surrounding the PSL threshold reset dates. Each point plotted in the figure represents the average annualized delinquency rate for loans disbursed in an interval of 50 basis points of the prevailing PSL threshold. We do not distinguish the four reset dates from one another in these pictures, but we do separately identify delinquency rates for loans issued pre-reset (using squares) from those for loans issued post-reset (using diamonds). The solid line in the figure, which averages the delinquency rates in a $+/-2 \%$ window around the pre-reset PSL-threshold, shows that loans just under the PSL-qualifying threshold, issued at times when we would expect the constraint to be the tightest, have higher annual delinquency rates than those loans just above the PSL-qualifying threshold.

The dotted lines in Figure 5 shows the effects of the threshold reset on delinquency rates for loans just above and below the new PSL-qualifying threshold. The large difference in delinquency rates around the PSL-qualifying threshold now becomes imperceptible, as we might expect if the constraint is relaxed to the point at which the PSL regulation no longer binds.

Figure 5 does not incorporate any difference in interest rates around the regulatory threshold. In order to examine delinquencies in relation to interest rates, we estimate regulatory effects on delinquencies using equations (1) and (2). The estimates are reported in Table 5, using both six-month and a shorter three-month time window. We show results for a $2 \%$ loan size window around the PSL threshold (our base case), and also for windows of $1.5 \%, 2.5 \%$, and $3 \%$.

Table 5 shows that in our base case, the delinquency rate (conditional on the initial interest rate) is significantly higher for mortgages just below the PSL threshold than just above the threshold, in the months before threshold resets, when the constraint is tightest: $\tau_{\text {old,below }}-\tau_{\text {old,above }}>0$. The difference in delinquency rates is roughly $47 \%$ of our lender's mean delinquency rate. Immediately after a threshold reset, however, this difference in delinquency rates disappears, consistent with a loosening of the constraint: 
$\tau_{\text {old,below }}-\tau_{\text {old,above }} \approx 0 . \quad$ As a result, the difference in difference is significantly positive: $\left(\tau_{\text {old,below }}-\tau_{\text {old,above }}\right)-\left(\tau_{\text {new,below }}-\tau_{\text {new,above }}\right)>0$.

Controlling for disbursal cohort, in the period immediately before a PSL threshold reset, interest rates at issuance for loans just below the PSL threshold are 69 basis points on average higher than on loans just above the threshold. However, this difference in initial interest rates can only explain roughly $20 \%$ of the observed difference in delinquency rates around the threshold. The remaining $80 \%$ is the effect we estimate above.

While these results are not particularly sensitive to the size of the time window around the date of the PSL threshold resets, our results do weaken as we include loans further away from the PSL-qualifying threshold. Disbursed loans of sizes infinitesimally greater than the PSL threshold have very low delinquency rates, perhaps because the lender is only willing to make such loans to especially reliable borrowers, without forcing the borrower into a slightly smaller PSL-qualifying loan, despite the obvious incentives to do so. In contrast, loans two to three percent above the PSL threshold experience delinquency rates which are closer to the average, tempering estimates as these loans enter the sample.

In the appendix we report estimates of a linear model, estimated using NLLS or OLS and a $2 \%$ loan size window. These estimates are broadly consistent with those for the Cox proportional hazard model reported in Table 5.

\section{An alternative specification}

As an alternative approach, using the same sample of loans, we replace the discrete treatment dummies with a variable PSLTightness $s_{i}$. This variable proxies for the intensity of the pressure faced by the lender at loan disbursal under the assumption that PSL threshold levels are reset to just relax the prevailing constraint. ${ }^{8}$ Specifically, during the three or sixmonth periods prior to the threshold resets, for PSL-qualifying loans, we set PSLTightness equal to the natural logarithm of the ratio of the new nominal PSL threshold to the old

\footnotetext{
${ }^{8}$ As before, we restrict the sample to the short window around the reset dates, and to loans just above and below the threshold, to generate maximal comparability between loans being compared in the usual RDD fashion.
} 
nominal PSL threshold. The variable takes the value of zero for loans disbursed after the threshold resets or above the PSL threshold.

We model:

$$
\operatorname{Pr}\left[\delta_{i, t}\right]=Z_{t-1} \exp \left(\alpha_{c}+\beta r_{i}+\eta \text { PSLTightness } s_{i}\right)+e_{i, t} .
$$

When PSLTightness is higher at the time of disbursing loan $i$, we expect that the PSL norm is more difficult to meet, consequently raising pressure on the lender to make lowerquality loans. We therefore expect $\eta>0$. Panel B of Table 5 shows that this approach does not yield significant results, perhaps owing to noise in the construction of our PSLTightness proxy.

\subsection{Regulation and Delinquencies: Risk Weights}

We now turn to analyzing the impact of risk-weight regulations on loan delinquency rates. In the early part of our sample, all mortgage loans had the same risk weights in India, 100 percent of the issued amount. In early 2002, the Reserve Bank of India decreased risk weights, and hence capital requirements, on loans with LTV ratios of 75 percent or lower. Subsequently, the risk weights on these less leveraged loans fluctuated between 50 or 75 percent. ${ }^{9}$

We test the hypothesis that the impact of these regulatory changes is to change incentives for lending at different LTV ratios, and hence, to affect delinquency rates on loans issued at these different LTV levels, conditional on initial interest rates. As an illustration, in April 2002, each rupee of bank capital would allow the lending of 12.5 rupees to high and low LTV borrowers given the provisioning requirements against $100 \%$ risk weights. As a consequence, we expect that the interest-rate-adjusted delinquency rates on loans to the two types of borrowers should be similar for loans issued during this period. However following the regulatory change, in June 2002, a rupee of capital allows a bank to lend 25 rupees to

\footnotetext{
${ }^{9}$ The Reserve Bank of India also applied larger risk weights to mortgage loans above 75 lakh rupees. However, we have very few mortgage loans this large in the sample, and are therefore unable to draw inferences from this source of variation.
} 
any borrower who wishes to borrow at an LTV ratio of $75 \%$ or lower. All else equal, holding the less leveraged loans now allows for a greater return on the bank's capital. The same story applies to housing finance companies, with slightly adjusted dates and risk weights (see Figure 3). We expect financial institutions to respond to this regulatory incentive by extending greater amounts of credit to lower leverage loans following downward adjustments in their risk weights, with a concomitant increase in excess delinquencies observed on these lower leverage loans.

To begin with, we plot the simple average of delinquency rates in a window of six months surrounding the dates on which risk-weights on less-leveraged loans change. In Figure 6, each plotted point represents the average annualized delinquency rate for loans disbursed at each percentage point loan-cost ratio shown on the horizontal axis. Again, we do not distinguish the individual change dates from one another in these pictures. We do, however, separately average delinquency rates for loans issued when the difference between risk-weights on highly leveraged and less-leveraged loans is relatively low, at 0 or $25 \%$ (represented by diamonds), from those issued when the difference in risk-weights is substantial, at $50 \%$ (squares).

The solid line in the figure, which averages the delinquency rates in a $+/-2 \%$ window around the loan-cost ratio qualifying threshold, shows that loans just under this threshold, issued when risk weights significantly favour less leveraged loans, are slightly more likely to be delinquent than loans with slightly higher leverage, immediately above the regulatory threshold. This is a striking result because delinquencies normally increase with the LTV ratio (see for example Campbell and Cocco 2014). The dotted line in Figure 6 shows that when the difference in risk weights is either zero or small, the delinquency rate is indeed slightly higher for more highly leveraged loans as one would normally expect. As in Figure 5 , these results do not control for the initial interest rates on loans.

Next, we adapt the framework outlined in equation (1) to compare delinquencies on loans disbursed just below/at and just above a 75 percent loan-to-cost ratio (which we measure at loan disbursal), just before and after the upward or downward adjustment of the risk weights on less leveraged loans, while controlling for initial interest rates. When the risk weights on less leveraged loans are adjusted downwards, we denote those disbursed before 
the adjustment (when risk weights are relatively close together) with the subscript close, and denote those disbursed after the risk weight adjustment (when risk weights are further apart) with the subscript far. When the risk weights on less leveraged loans are adjusted upwards, we denote those disbursed before the adjustment (when risk weights are relatively far apart) with the subscript far, and denote those disbursed after the risk weight adjustment (when risk weights are closer together) with the superscript close. Thus, to assess the impacts of the risk-weight changes on the delinquency rates of loans with different LTVs we model $\tau^{\prime} D_{i}$ in equation (1) as:

$$
\begin{aligned}
\tau^{\prime} D_{i} & =\tau_{\text {close }, \text { below }} D_{i, \text { close }, \text { below }}+\tau_{\text {close }, \text { above }} D_{i, \text { close }, \text { above }} \\
& +\tau_{\text {far,below }} D_{i, \text { far }, \text { below }}+\tau_{\text {far }, \text { above }} D_{i, \text { far }, \text { above }}
\end{aligned}
$$

where $D_{i, \text { close,below }}$ is a dummy variable for loans with a loan-to-cost ratio $\leq 0.75$, issued when the risk weights across loans of varying leverage are closer together; $D_{i, c l o s e, a b o v e}$ is a dummy variable for loans with a loan-to-cost ratio $>0.75$, issued when the risk weights across loans of varying leverage are closer together; $D_{i, \text { far,below }}$ is a dummy variable for loans with a loanto-cost ratio $\leq 0.75$, issued when the risk weights across loans of varying leverage are further apart; and $D_{i, f a r, a b o v e}$ is a dummy variable for loans with a loan-to-cost ratio $>0.75$, issued when the risk weights across loans of varying leverage are further apart.

Following the reasoning described above, we expect that

$$
\tau_{\text {far,below }}-\tau_{\text {far,above }}>\left(\tau_{\text {far,below }}-\tau_{\text {far,above }}\right)-\left(\tau_{\text {close,below }}-\tau_{\text {close,above }}\right) \geq 0
$$

We test both these inequalities below.

\section{Delinquencies around risk weight changes}

We estimate risk-weight effects on delinquencies using equations (1) and (5). The estimates are reported in Table 6, using both six and three-month time windows. We show 
results for a $2 \%$ leverage ratio window around the risk weight threshold (our base case), and also for windows of $1 \%$ and $3 \%$.

We find some evidence in support of the inequalities in equation (6). Our estimates of $\tau_{\text {far,below }}-\tau_{\text {far,above }}$ and $\left(\tau_{\text {far,below }}-\tau_{\text {far,above }}\right)-\left(\tau_{\text {close,below }}-\tau_{\text {close,above }}\right)$ are almost always positive. However, the null hypotheses that these differences are zero can only be rejected when we use a narrow three-month time window and a leverage ratio window of $1 \%$ or $2 \%$.

\section{A continuous approach}

Here, we assume that the interest-rate-adjusted difference in delinquencies on loans with just above and below 75 percent loan-cost is proportional to the difference in risk weights on these mortgages. Specifically, we construct RiskWeightAdvantage is $_{i}$ the amount by which the risk weight prevailing at the time of loan $i$ 's disbursal falls below the $100 \%$ risk weight on more highly levered loans. For less levered loans, RiskWeightAdvantage varies between zero and 0.5, and for loans with LTV > 75\%, this variable takes the value of zero. We then estimate

$$
\operatorname{Pr}\left[\delta_{i, t}\right]=Z_{t-1} \exp \left(\alpha_{c}+\beta r_{i}+\eta \text { RiskWeightAdvantage }_{i}\right)+e_{i, t}
$$

Panel B of Table 6 shows that when we estimate this model we almost always find $\eta>0$ as expected. The coefficient estimates are always statistically significant when we use a three-month time window around the changes in risk weights. The three-month estimate for the base case with a $2 \%$ leverage window imply that the largest advantage in risk weights given to less leveraged mortgages resulted in increased delinquencies of these mortgages by roughly $30 \%$ of the population average delinquency rate (risk weight advantage of 0.5 times a coefficient of 0.59$)$. 


\section{Reclassification of Non-Performing Assets}

In this section we examine another regulatory change that took place during our sample period. On March 31, 2004 for banks, and March 31, 2005 for HFCs, the classification of "non-performing assets" (or NPAs) was changed to 90 days past due from the previous time period of 180 days past due. This regulatory reclassification of 90-day delinquencies, and its implications for provisioning requirements, may have contributed to the sharp decline in 90day delinquency rates seen in Figure 4. One mechanism by which this might occur is that the reclassification may have given our mortgage lender the incentive to more intensively monitor shorter-term delinquencies (say 30 days past due), and to take earlier action to forestall 90-day delinquency.

To evaluate this, we look at the expected loss given shorter-term delinquency before and after our lender adopted the regulatory reclassification, which was a short time before it was officially mandatory (March 2004 for banks, April 2005 for housing finance companies). ${ }^{10}$ Expected loss is the product of the probability of experiencing a longer-term delinquency and the loss given longer-term delinquency. Table 7 looks at the first of these two elements, computing transition probabilities of loans that hit the 30-day delinquency threshold to the 90-day delinquency mark, as well as the transition probability of 90-day delinquencies to the 180-day delinquent mark.

The table shows that across the entire sample period, $22.7 \%(22.8 \%)$ of 30 -day (90day) delinquent loans eventually become 90 days (180 days) delinquent. However, in the period prior to our lender's adoption of the NPA reclassification, the 30 to 90 day delinquent transition probability was $29.2 \%$, almost twice the post-adoption transition probability of 16.0\%. The reduction, of $13.3 \%$ is highly statistically significant. The lender may have substantially reduced this transition probability by exerting effort to pursue borrowers more aggressively to avoid the build up of non-performing assets. The 90-day to 180-day transition

\footnotetext{
${ }^{10}$ While we are unable to identify the precise date when the lender adopted the regulation in the interests of preserving anonymity, this occurred not too distant from when the change in regulation became mandatory for banks. It does not make much difference to our results when we use the official date rather than the date at which the lender implemented the change internally.
} 
probability falls by a negligible $1.3 \%$ following the adoption of the reclassification. This suggests there are relatively fewer incentives to take action in the post adoption period once the loan has already been classified as a non-performing asset (and as the 180 day definition looms in the pre-adoption period). Another possibility is that loans past the 90day delinquency mark are simply very difficult to collect on despite the lender's exertions. ${ }^{11}$

To better understand the magnitude of loss given delinquency, we acquire a sample of 10,000 loans from the total population of loans. As our focus is to understand the determinants of mortgage risk, we randomly sample 2,500 fixed-rate and 2,500 variablerate loans from the set of 90-day delinquent loans, and a further 2,500 fixed-rate and 2,500 variable-rate loans from the set of loans that do not experience a 90-day delinquency. In each sub-sample of 2,500 loans, we further ensure that we sample an equal number $(1,250)$ from the early period in the data (disbursed prior to January 2000) and the later period (disbursed between January 2000 and December 2004). We have verified that this 10,000 loan sample has statistically indistinguishable characteristics from the population of loans from which we draw. For each one of these 10,000 loans, we are able to track the full payment history over time, as well as deviations from contracted repayments. We can compute the latter as we are also given the equated monthly installment (EMI) for each of these loans in each month, which is the expected monthly principal repayment plus interest amount. We ensure that we weight any measures constructed using this sample, so that they are reflective of the larger population of loans from which the sampling occurred.

For each loan in the sample, we construct a measure of losses accrued over time. To do so, we accumulate payments and EMI over time, and compute the "cumulative installment deficit" (or CID) as Min(0, cumulative payment-cumulative EMI)/EMI. This measure takes the value of zero if monthly payments exceed or equal the EMI, and is negative otherwise, indicating when borrowers are in arrears. The cumulation ensures that if overpayments are

\footnotetext{
${ }^{11}$ The 2002 implementation of SARFAESI, described above, allowed for easier restructuring and repossession of delinquent loans. However the small change in the 90-180 day transition probability despite this regulatory change mirrors the insignificant post-SARFAESI change in the $\triangle$ CID debt collection rate that we define and analyze below. These results suggest that at least for housing loans, this particular regulatory change may not have had very large effects.
} 
made to redress arrears, these are allowed to push the measure towards zero. The division by EMI puts the cumulative installment deficit into units of required monthly payments.

Figure 7 plots the CID measure around 30-day delinquencies, before and after our lender adopted the reclassification of NPAs. The measure is cross-sectionally demeaned by both cohort-year and calendar-year, to ensure that we are not picking up cohort or macroeconomic effects. In both panels of Figure 7, date 0 is the first date that the loan is declared 30-days delinquent (values below 1 are possible because of the cross-sectional demeaning). The top panel shows that prior to the change in the regulatory definition of NPAs, loans declared 30-days delinquent on average inflicted a cost on the mortgage provider of roughly 1.1 EMIs after a year. Post-March 2004, there is a substantial recovery in this number, with such 30-delinquent loans roughly 0.4 EMIs delinquent 12 months later. The bottom panel of the figure shows that this change in the behavior of the CID after the regulatory redefinition of NPAs is highly statistically significant.

We undertake this analysis more formally by estimating how changes in the CID vary following a 30-day delinquency, but prior to hitting the 90-day threshold, both before and after the regulatory redefinition of the NPA period. To do so, we estimate expected debt collection rates - changes in the CID - as a polynomial function of the level of the CID prior to the 90-day delinquency mark (i.e., a CID level of -3), allowing for a jump in the rate at the 90-day delinquency mark, and modelled as a linear function of the CID beyond the 90day delinquency mark. As before, we include time- and cohort-specific fixed effects during estimation to ensure that we are not merely picking up some of the broader changes detected earlier in the regulatory and macroeconomic environment.

Figure 8 shows how the estimated debt collection rate varies before and after the 90-day delinquency threshold, before and after the regulatory reclassification of NPAs was adopted. The figure reveals that following the adoption of the reclassification, the debt collection rate prior to hitting the 90-day mark increased substantially relative to the pre-adoption period, with a significant discontinuity at the 90-day threshold, where the debt collection rate falls sharply. ${ }^{12}$ We also consider whether the introduction of SARFAESI had any

\footnotetext{
${ }^{12}$ The increase in the debt collection rate prior to the 90-day delinquency mark, and the discontinuity
} 
significant impacts on the ability to collect on debts, and find that differences are minimal and statistically insignificant.

While these changes to debt collection rates are evident in the data, one potential interpretation is that the redefinition of NPAs from 180 to 90 days simply shifted the inevitable recovery of cash from delinquent borrowers by the 90-day difference between these two dates. In other words, perhaps the change merely provided a time-value improvement in the net cash flows of the mortgage provider, but no more substantial impacts.

To address this question, Figure 9 shows the cumulative distribution function (CDF) of the change in the CID (time- and cohort-demeaned) in the year following the first 30 day delinquency. This CDF is plotted for three time periods, namely, January 1995 to June 2002, when SARFAESI was first implemented; July 2002 to the date our lender adopted a reclassification of NPAs; and from this adoption date until the end of the sample period in 2010. We plot the figure on a log scale to focus attention on the very worst cases (i.e., those loans with the greatest degradation in CID over the year following the date of first 30-day delinquency), as these loans are the most likely candidates for a complete write-off.

The figure shows that the post-NPA redefinition CDF first-order stochastically dominates both the pre- and post-SARFAESI CDFs, showing a substantial reduction in the incidence of high degradation in the CID. While SARFAESI appears to have had some beneficial impacts for the very worst cases, this is dwarfed by the large impact of the NPA redefinition. These substantial impacts on eventual bad debts of this regulatory redefinition are striking, as it appears that there are important benefits to incentivizing mortgage providers to detect and take early action on delinquencies.

In Figure 10 we document some evidence that the change in the regulatory classification of NPAs affected screening at mortgage origination as well as mortgage monitoring practices. This figure reports the same curve as in Figure 9, separately for loans originated in six-month windows before and after the NPA reclassification was adopted by our lender. The left tail

at that mark are both economically and statistically significant. The online empirical appendix plots the difference between the pre- and post-adoption debt collection rates with associated bootstrap confidence intervals. 
of the distribution is noticeably thicker for loans originated before the reclassification. Since we are observing delinquency experiences for both cohorts of loans over the same postreclassification period (with presumably enhanced monitoring), the reduced probability of very bad outcomes for loans issued post-adoption is evidence that mortgage screening at origination was heightened as well.

In summary, a simple change in the regulatory definition of NPAs appears to have significantly moderated mortgage delinquencies. The impacts are visible in both the probability of delinquency and the eventual loss given delinquency.

A natural question that arises here is why the lender did not implement such changes to monitoring voluntarily, earlier than the regulatory imposition of the change, given the significant impacts on short- and long-term delinquency rates. The issue here is that loan screening and monitoring are costly, and we do not measure the costs. Given that we do not (and cannot feasibly) assess these costs, we are unable to assess the net impact on the lender of implementing quicker action on potentially delinquent loans, despite documenting that the benefits of such monitoring are large. It is also possible that tougher screening, by reducing credit extended to lower quality borrowers, conflicts with the lender's incentives to lend to the priority sector and may incur political or public relations costs.

\section{Conclusion}

The Indian regulatory and macroeconomic environment has changed dramatically during the last two decades. A fast-developing housing finance system has coped with significant variation in default rates and interest rates, and regulatory changes in the incentives to originate mortgages in general, and small loans in particular. In this paper we have explored the effects of such regulatory changes on mortgage risk using an empirical strategy that links time variation in regulation with expected cross-sectional impacts on different types of mortgages.

We have presented evidence that regulatory subsidies for low-cost housing and less leveraged loans are associated with higher delinquencies, controlling for interest rates at loan 
issuance, and that changes to the definition of non-performing assets impacted behavior in response to early evidence of payment delinquencies. While it is difficult to generalize findings from one country, or to make welfare statements in the absence of a full estimation of both costs and benefits, our findings on the infrequent adjustment of PSL-thresholds suggest that paying attention to the design of policies may yield rewards, and the estimated effect of the regulatory redefinition of NPAs suggests that even seemingly minor regulatory changes can have important impacts on mortgage monitoring and origination practices, and hence on mortgage risk. 


\section{References}

Acharya, Viral V., Matthew Richardson, Stijn van Nieuwerburgh, and Lawrence J. White, 2011, Guaranteed to Fail: Fannie Mae, Freddie Mac, and the Debacle of Mortgage Finance, Princeton University Press, Princeton, NJ.

Adelino, Manuel, Kristopher Gerardi, and Paul S. Willen, 2013, "Why Don't Lenders Renegotiate More Home Mortgages? Redefaults, Self-Cures, and Securitization", Journal of Monetary Economics 60, 835-853.

Adelino, Manuel, Antoinette Schoar, and Felipe Severino, 2014, "Credit Supply and House Prices: Evidence from Mortgage Market Segmentation", unpublished paper, Duke University and MIT.

Agarwal, Sumit, Gene Amromin, Itzhak Ben-David, Souphala Chomsisengphet, and Douglas D. Evanoff, 2011, "The Role of Securitization in Mortgage Renegotiation", Journal of Financial Economics 102, 559-578.

Agarwal, Sumit, Efraim Benmelech, Nittai Bergman, and Amit Seru, 2012, "Did the Community Reinvestment Act (CRA) Lead to Risky Lending?", NBER Working Paper No. 18609.

Aghion, Philippe, Robin Burgess, Stephen J. Redding, and Fabrizio Zilibotti, 2008, "The Unequal Effects of Liberalization: Evidence from Dismantling the License Raj in India", American Economic Review, 98(4), 1397-1412.

Amromin, Gene, Jennifer Huang, Clemens Sialm, and Edward Zhong, 2011, "Complex Mortgages," NBER Working Paper No. 17315.

Anagol, Santosh, and Hugh Kim, 2012, "The Impact of Shrouded Fees: Evidence from a Natural Experiment in the Indian Mutual Funds Market", American Economic Review, 102(1), 576-593. 
Avery, Robert, and Ken Brevoort, 2011, "The Subprime Crisis: Is Government Housing Policy to Blame?," FEDS Working Paper 2011-36, Federal Reserve Board.

Baily, Martin N., 2011, ed., The Future of Housing Finance: Restructuring the U.S. Residential Mortgage Market, Brookings Institution Press, Washington, DC.

Balasubramanyan, Lakshmi, and Kevin Jacques, 2011, "Risk Weights in Regulatory Capital Standards: Is it Necessary to 'Get It Right'?," Networks Financial Institute Working Paper No. 2011-23.

Banerjee, Abhijeet, Shawn Cole, Esther Duflo, and Leigh Linden, 2007, "Remedying Education: Evidence from Two Randomized Experiments in India," Quarterly Journal of Economics, 122(3), 1235-1264.

Besley, Tim, and Robin Burgess, 2000, "Land Reform, Poverty Reduction and Growth: Evidence from India", Quarterly Journal of Economics 115, 389-430.

Bhutta, Neil, Jane Dokko, and Hui Shan, 2010, "The Depth of Negative Equity and Mortgage Default Decisions," FEDS Working Paper 2010-35, Federal Reserve Board.

Calem, Paul, and James Follain, 2007, "Regulatory Capital Arbitrage and the Potential Competitive Impact of Basel II in the Market for Residential Mortgages", Journal of Real Estate Finance and Economics 35, 197-219.

Campbell, John Y., 2013, "Mortgage Market Design", Review of Finance 17, 1-33.

Campbell, John Y. and Joao F. Cocco, 2014, "A Model of Mortgage Default", forthcoming Journal of Finance.

Campbell, John Y., Stefano Giglio, and Parag Pathak, 2011, "Forced Sales and House Prices", American Economic Review 101, 2108-2131.

Campbell, John Y., Tarun Ramadorai, and Vimal Balasubramaniam, 2014, "Prudential Regulation of Housing Finance in India 1995-2011", regulatory appendix, available at: http://intranet.sbs.ox.ac.uk/tarun_ramadorai/TarunPapers/PrudentialRegulationAppendix.pdf. 
Campbell, John Y., Tarun Ramadorai, and Benjamin Ranish, 2014, "Appendix to Campbell, Ramadorai, and Ranish", empirical appendix, available at: http://intranet.sbs.ox.ac.uk/tarun_ramadorai/TarunPapers/MortgageEmpiricalAppendix.pdf.

Campbell, Tim S. and J. Kimball Dietrich, 1983, "The Determinants of Default on Insured Conventional Residential Mortgage Loans", Journal of Finance 38, 1569-1581.

Canner, Glenn and Wayne Passmore, 1997, "The Community Reinvestment Act and the Profitability of Mortgage-Oriented Banks", unpublished paper, Federal Reserve Board.

Cole, Shawn A., 2009, "Fixing Market Failures or Fixing Elections? Elections, Banks and Agricultural Lending in India", American Economic Journal: Applied Economics 1, $219-50$.

Cox, David R., 1972, "Regression Models and Life Tables", Journal of the Royal Statistical Society B, 34, 187-220.

Dahl, Drew, Douglass Evanoff, and Michael Spivey, 2000, "Does the Community Reinvestment Act Influence Lending? An Analysis of Changes in Bank Low-Income Mortgage Activity,” Working Paper No. 2000-06, Federal Reserve Bank of Chicago

DeFusco, Anthony, and Andrew Paciorek, 2014, "The Interest Rate Elasticity of Mortgage Demand: Evidence from Bunching at the Conforming Loan Limit", FEDS Working Paper 2014-11, Federal Reserve Board.

Demyanyk, Yuliya, and Otto van Hemert, 2011, "Understanding the Subprime Mortgage Crisis", Review of Financial Studies 24, 1848-1880.

Duca, John V. and Stuart S. Rosenthal, 1994, "Do Mortgage Rates Vary Based on Household Default Characteristics? Evidence Based on Rate Sorting and Credit Rationing", Journal of Real Estate Finance and Economics 8, 99-113.

Ellis, Luci, 2008, "The Housing Meltdown: Why Did It Happen in the United States?", Bank for International Settlements Working Paper 259. 
Foote, Christopher, Kristopher Gerardi, Lorenz Goette, and Paul Willen, 2010, "Reducing Foreclosures: No Easy Answers," NBER Macroeconomics Annual 2009, 89-138.

Hunt, Stefan, 2010, "Informed Traders and Convergence to Market Efficiency: Evidence from a New Commodity Futures Exchange", unpublished paper, Harvard University.

International Monetary Fund, 2011, "Housing Finance and Financial Stability-Back to Basics?", Chapter 3 in Global Financial Stability Report, April 2011: Durable Financial Stability - Getting There from Here, International Monetary Fund, Washington, DC.

Johnson, Kathleen W. and Geng Li, 2011, "Are Adjustable-Rate Mortgage Borrowers Borrowing Constrained?", forthcoming Real Estate Economics.

Kashyap, Anil, Raghuram Rajan, and Jeremy Stein, 2008, "Rethinking Capital Regulation", in Federal Reserve Bank of Kansas City Symposium on Maintaining Stability in a Changing Financial System, 431-471.

Keys, Benjamin, Tanmoy Mukherjee, Amit Seru, and Vikrant Vig, 2010, "Did Securitization Lead to Lax Screening? Evidence from Subprime Loans", Quarterly Journal of Economics 125, 307-362.

Kroszner, Randall, 2008, "The Community Reinvestment Act and the Recent Mortgage Crisis," speech at the Confronting Concentrated Poverty Policy Forum.

von Lilienfeld-Toal, Dilip Mookherjee and Sujata Visaria, 2012, "The Distributive Impact of Reforms in Credit Enforcement: Evidence from Indian Debt Recovery Tribunals", Econometrica, 89, 497-558.

Melzer, Brian T., 2011, "Mortgage Debt Overhang: Reduced Investment by Homeowners with Negative Equity", unpublished paper, Northwestern University.

Mian, Atif and Amir Sufi, 2009, "The Consequences of Mortgage Credit Expansion: Evidence from the U.S. Mortgage Default Crisis", Quarterly Journal of Economics 124, $1449-1496$. 
Piskorski, Tomasz, Amit Seru, and Vikrant Vig, 2011, "Securitization and Distressed Loan Renegotiation: Evidence from the Subprime Mortgage Crisis", Journal of Financial Economics 97, 369-397.

Tiwari, Piyush and Pradeep Debata, 2008, "Mortgage Market in India", Chapter 2 in Danny Ben-Shahar, Charles Ka Yui Leung, and Seow Eng Ong eds. Mortgage Markets Worldwide, Blackwell.

U.S. Treasury and Department of Housing and Urban Development, 2011, Reforming America's Housing Market: A Report to Congress, Washington, DC.

Verma, R.V., 2012, "Evolution of the Indian Housing Finance System and Housing Market", Chapter 14 in Ashok Bardhan, Robert H. Edelstein, and Cynthia A. Kroll eds. Global Housing Markets: Crises, Policies, and Institutions, John Wiley.

Vig, V., 2013, "Access to Collateral and Corporate Debt Structure: Evidence from a Natural Experiment," Journal of Finance, 68, 881-928.

Wooldridge, Jeffrey M., 2002, Econometric Analysis of Cross Section and Panel Data, MIT Press, Cambridge, MA. 


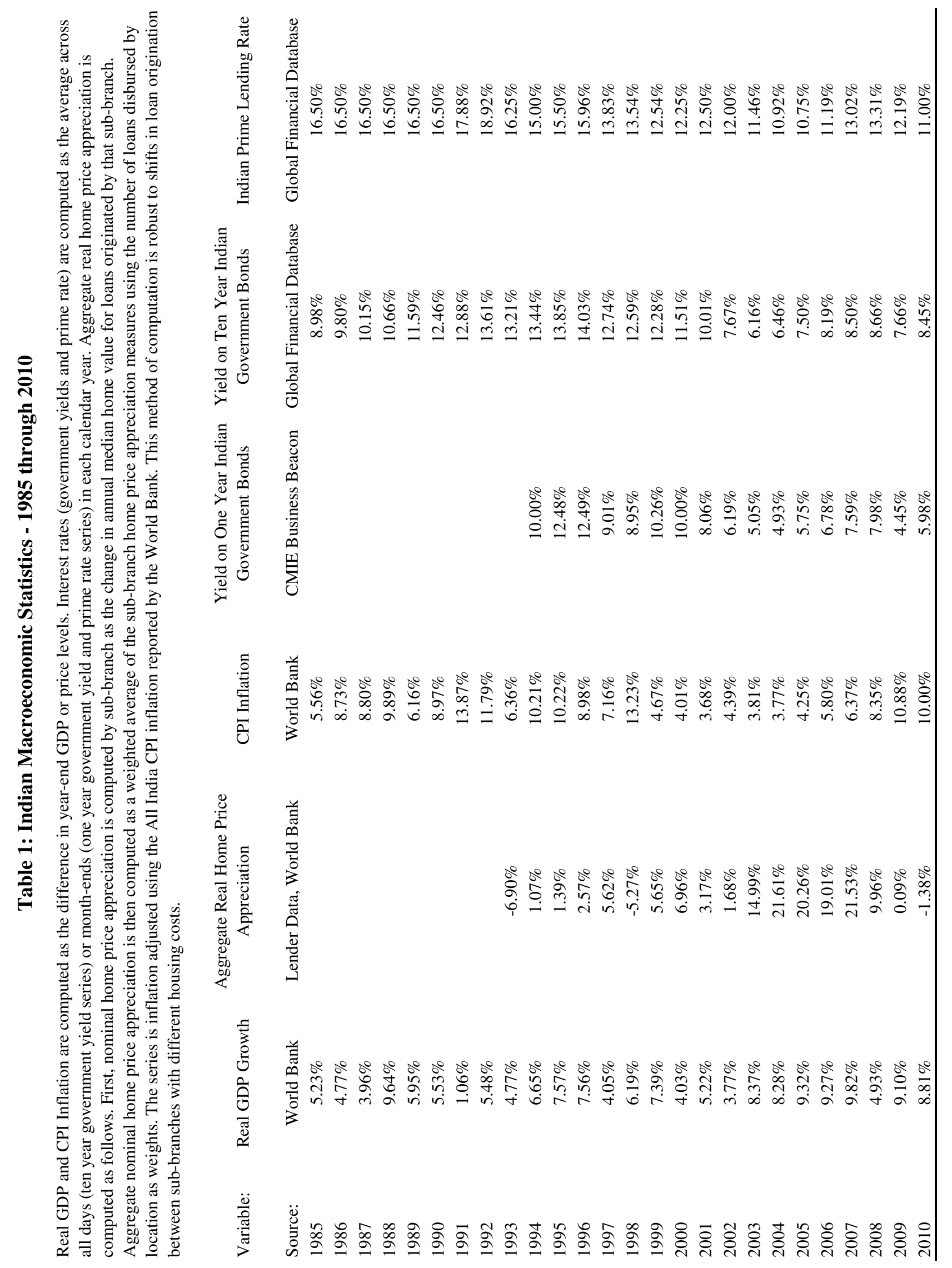




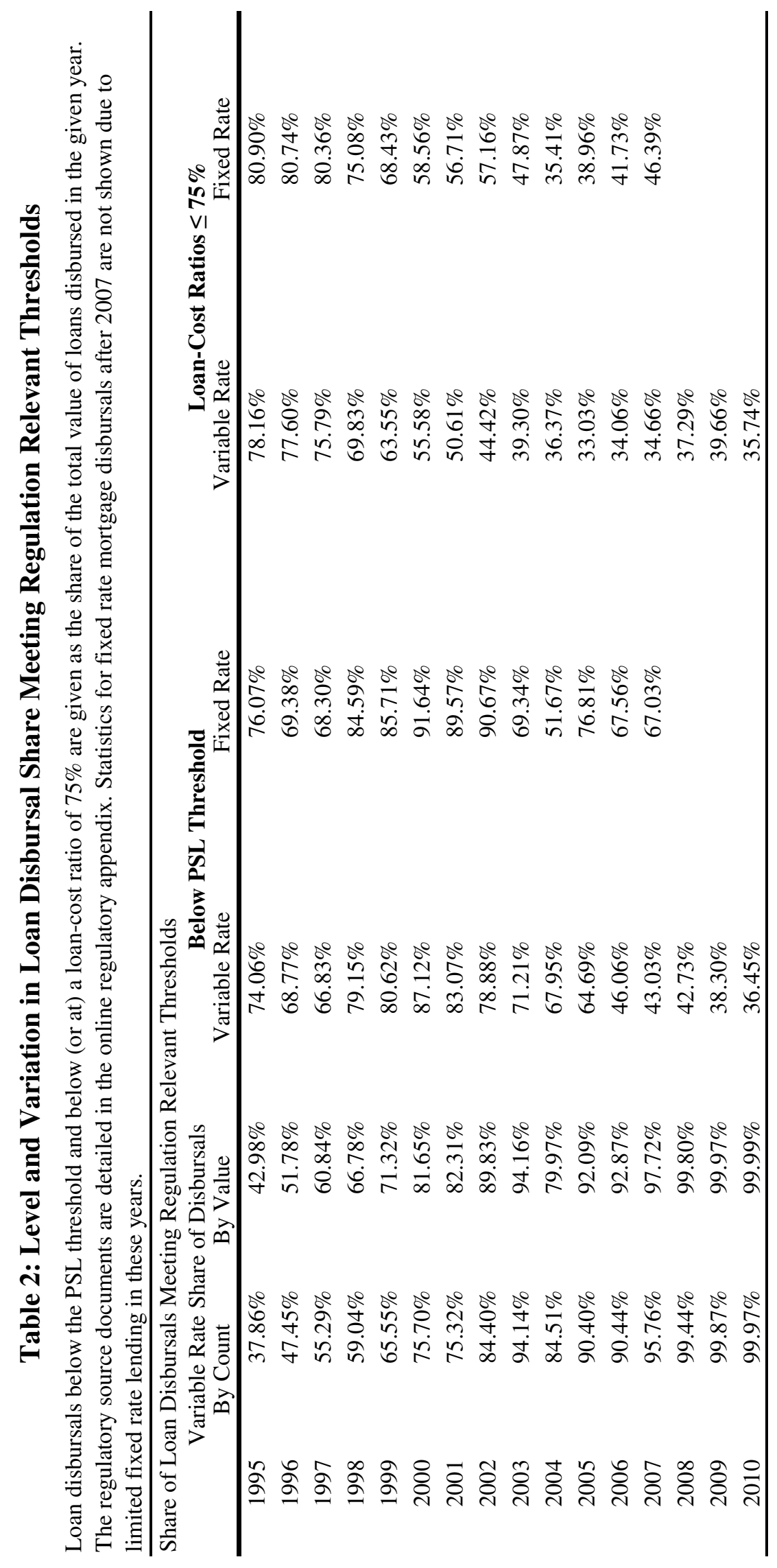




\section{Table 3: Summary Statistics on Loan Characteristics by Disbursal Year}

This table provides equal-weighted yearly means (Panel A) and standard deviations (Panel B) of important characteristics for the more than 1.2 million mortgage loans disbursed by the lender. Cohort delinquency rates are computed as the annual probability that an outstanding and not-yet-90day-delinquent loan experiences a 90 day delinquency. This probability is computed separately for each disbursal-year cohort and calendar year. The delinquency rate below represents the time-series average across calendar year estimates for each disbursal-year cohort. Statistics for fixed rate disbursals are removed for the years 2008 through 2010, as fixed rate disbursals account for well under one percent of disbursals (by count or value) in each of these years. Similarly, cohort 90-day delinquency rate is omitted for loans disbursed after 2007 as these loans have not been around long enough to reliably estimate a delinquency rate.

\begin{tabular}{|c|c|c|c|c|c|c|c|c|c|c|}
\hline \multicolumn{11}{|c|}{ A: Cross-Sectional Means } \\
\hline & \multicolumn{2}{|c|}{ Initial Interest Rate } & \multicolumn{2}{|c|}{ Loan Term (Years) } & \multicolumn{2}{|c|}{ Loan-Cost Ratio } & \multicolumn{2}{|c|}{ Loan-Income Ratio } & \multicolumn{2}{|c|}{ Cohort 90-Day Delinquency Rate } \\
\hline & Variable & Fixed & Variable & Fixed & Variable & Fixed & Variable & Fixed & Variable & Fixed \\
\hline 1995 & $15.22 \%$ & $15.00 \%$ & 13.96 & 11.66 & 0.58 & 0.54 & 3.73 & 3.52 & $1.70 \%$ & $2.27 \%$ \\
\hline 1996 & $16.39 \%$ & $16.14 \%$ & 13.21 & 10.89 & 0.57 & 0.54 & 3.69 & 3.45 & $1.98 \%$ & $2.56 \%$ \\
\hline 1997 & $15.54 \%$ & $15.25 \%$ & 13.18 & 10.38 & 0.58 & 0.55 & 3.69 & 3.38 & $1.76 \%$ & $2.79 \%$ \\
\hline 1998 & $14.45 \%$ & $14.09 \%$ & 13.08 & 10.06 & 0.61 & 0.57 & 3.67 & 3.28 & $1.84 \%$ & $3.12 \%$ \\
\hline 1999 & $13.58 \%$ & $13.39 \%$ & 12.88 & 10.63 & 0.64 & 0.61 & 3.62 & 3.31 & $1.78 \%$ & $4.38 \%$ \\
\hline 2000 & $12.58 \%$ & $12.83 \%$ & 12.95 & 10.55 & 0.67 & 0.67 & 3.58 & 3.20 & $2.13 \%$ & $4.58 \%$ \\
\hline 2001 & $11.78 \%$ & $11.76 \%$ & 12.72 & 10.23 & 0.68 & 0.64 & 3.56 & 3.23 & $2.16 \%$ & $5.27 \%$ \\
\hline 2002 & $10.92 \%$ & $10.82 \%$ & 13.15 & 10.03 & 0.70 & 0.64 & 3.49 & 3.21 & $2.53 \%$ & $4.63 \%$ \\
\hline 2003 & $10.68 \%$ & $9.41 \%$ & 12.88 & 12.76 & 0.72 & 0.65 & 3.45 & 3.54 & $2.36 \%$ & $2.20 \%$ \\
\hline 2004 & $10.82 \%$ & $8.13 \%$ & 14.07 & 15.13 & 0.73 & 0.71 & 3.65 & 3.75 & $2.18 \%$ & $0.91 \%$ \\
\hline 2005 & $10.42 \%$ & $8.83 \%$ & 15.16 & 15.17 & 0.74 & 0.69 & 3.75 & 3.72 & $1.75 \%$ & $1.26 \%$ \\
\hline 2006 & $10.85 \%$ & $10.45 \%$ & 15.23 & 15.59 & 0.73 & 0.70 & 3.74 & 3.69 & $1.53 \%$ & $1.12 \%$ \\
\hline 2007 & $11.03 \%$ & $12.26 \%$ & 15.03 & 14.68 & 0.73 & 0.68 & 3.75 & 3.58 & $1.18 \%$ & $1.43 \%$ \\
\hline 2008 & $10.79 \%$ & & 15.38 & & 0.72 & & 3.78 & & & \\
\hline 2009 & $9.51 \%$ & & 14.31 & & 0.71 & & 3.72 & & & \\
\hline 2010 & $8.39 \%$ & & 15.59 & & 0.73 & & 3.84 & & & \\
\hline \multicolumn{11}{|c|}{ B: Cross-Sectional Standard Deviations } \\
\hline & \multicolumn{2}{|c|}{ Initial Interest Rate } & \multicolumn{2}{|c|}{ Loan Term (Years) } & \multicolumn{2}{|c|}{ Loan-Cost Ratio } & \multicolumn{2}{|c|}{ Loan-Income Ratio } & & \\
\hline & Variable & Fixed & Variable & Fixed & Variable & Fixed & Variable & Fixed & & \\
\hline 1995 & $0.94 \%$ & $1.13 \%$ & 2.51 & 4.24 & 0.18 & 0.20 & 0.47 & 0.71 & & \\
\hline 1996 & $1.28 \%$ & $1.53 \%$ & 2.73 & 4.26 & 0.18 & 0.20 & 0.49 & 0.74 & & \\
\hline 1997 & $0.84 \%$ & $1.22 \%$ & 2.72 & 4.49 & 0.18 & 0.20 & 0.51 & 0.83 & & \\
\hline 1998 & $0.71 \%$ & $1.09 \%$ & 2.81 & 4.69 & 0.18 & 0.20 & 0.51 & 0.86 & & \\
\hline 1999 & $0.51 \%$ & $0.77 \%$ & 3.00 & 4.52 & 0.18 & 0.19 & 0.52 & 0.80 & & \\
\hline 2000 & $1.21 \%$ & $0.85 \%$ & 3.61 & 4.57 & 0.18 & 0.19 & 0.57 & 0.85 & & \\
\hline 2001 & $1.06 \%$ & $0.97 \%$ & 3.97 & 4.56 & 0.18 & 0.24 & 0.61 & 0.83 & & \\
\hline 2002 & $1.46 \%$ & $0.92 \%$ & 4.43 & 4.63 & 0.19 & 0.24 & 0.70 & 0.81 & & \\
\hline 2003 & $2.08 \%$ & $0.89 \%$ & 4.85 & 4.77 & 0.19 & 0.26 & 0.78 & 0.67 & & \\
\hline 2004 & $2.04 \%$ & $0.60 \%$ & 4.97 & 4.55 & 0.18 & 0.21 & 0.72 & 0.59 & & \\
\hline 2005 & $1.73 \%$ & $0.48 \%$ & 4.92 & 4.52 & 0.18 & 0.22 & 0.68 & 0.60 & & \\
\hline 2006 & $1.24 \%$ & $0.76 \%$ & 4.95 & 4.48 & 0.18 & 0.22 & 0.70 & 0.63 & & \\
\hline 2007 & $0.67 \%$ & $1.00 \%$ & 4.41 & 4.78 & 0.18 & 0.23 & 0.69 & 0.71 & & \\
\hline 2008 & $0.59 \%$ & & 4.57 & & 0.18 & & 0.70 & & & \\
\hline 2009 & $0.77 \%$ & & 5.00 & & 0.18 & & 0.72 & & & \\
\hline 2010 & $0.37 \%$ & & 4.55 & & 0.17 & & 0.64 & & & \\
\hline
\end{tabular}




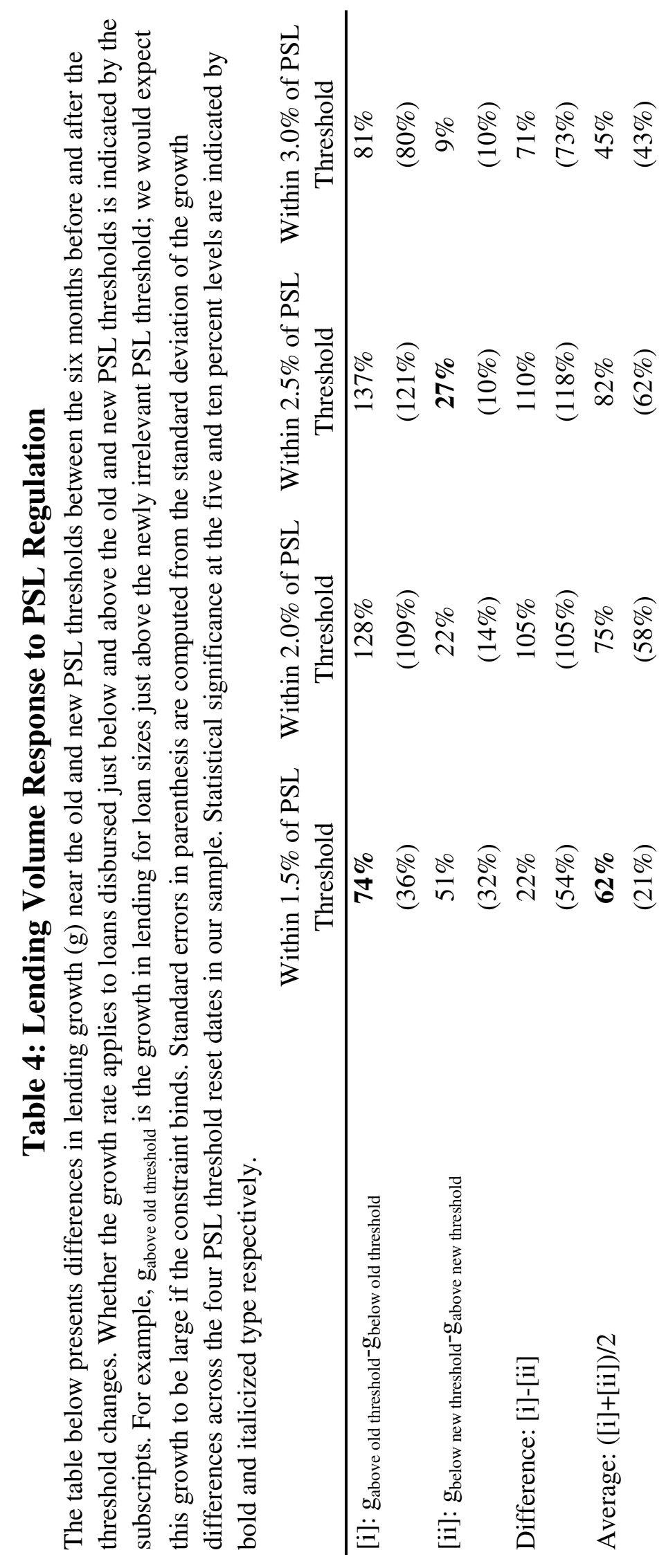




\section{Table 5: Impact of PSL Regulation on Abnormal Delinquency Rate}

This table provides parameters of interest from Equations 1 (in section A) and 4 (in section B) in the paper estimated as Cox hazard models on the population of loans disbursed around priority sector lending (PSL) thresholds around the time of PSL threshold changes. In section A, the reported differences represent the impact of PSL qualification on abnormal delinquency rates before [i] and after [ii] the PSL threshold is raised, relaxing the constraint. In section B, the coefficient $\eta$ represents the impact of our proxy for PSL constraint tightness (the natural log of the ratio of new-over-old PSL thresholds) on abnormal delinquency rates of PSL. Coefficients and standard errors are scaled to reflect the impact relative to the average delinquency rate in the full loan sample. Standard errors (reported in parentheses) are computed by bootstrapping years of the panel data, with bold and italicized type representing statistical significance at the five and ten percent level respectively.

Using a Six-month Time Window Around PSL Threshold Changes

\begin{tabular}{lcccc} 
Loan Size Window: & $1.5 \%$ & $2.0 \%$ & $2.5 \%$ & $3.0 \%$ \\
Observations (Above Threshold): & 812 & 1,378 & 1,810 & 2,307 \\
Observations (At/Below Threshold): & 31,738 & 32,400 & 33,086 & 33,561 \\
\multicolumn{2}{c}{ Using a Three-month Time Window } & Around PSL Threshold Changes & \\
Observations (Above Threshold): & 398 & 659 & 894 & 1,123 \\
Observations (At/Below Threshold): & 16,172 & 16,481 & 16,857 & 17,129 \\
\hline
\end{tabular}
A. Difference-in-Difference Specification (Equation 1)
Using a Six-month Time Window Around PSL Threshold Changes

$\begin{array}{lcccc}\text { [i]: } \tau_{\text {old,below }}-\tau_{\text {old,above }} & \mathbf{0 . 5 7} & \mathbf{0 . 4 7} & 0.15 & 0.07 \\ & (0.24) & (0.14) & (0.20) & (0.17) \\ \text { [ii]: } \tau_{\text {new,below }}-\tau_{\text {new,above }} & 0.35 & -0.07 & 0.07 & 0.04 \\ & (0.23) & (0.19) & (0.17) & (0.14) \\ \text { [i]-[ii] } & 0.22 & \mathbf{0 . 5 4} & 0.07 & 0.03 \\ & (0.23) & (0.23) & (0.30) & (0.24)\end{array}$

Using a Three-month Time Window Around PSL Threshold Changes

\begin{tabular}{lcccc} 
[i]: $\tau_{\text {old,below }}-\tau_{\text {old,above }}$ & 0.56 & $\mathbf{0 . 5 5}$ & 0.29 & 0.16 \\
& $(0.33)$ & $(0.15)$ & $(0.19)$ & $(0.21)$ \\
[ii]: $\tau_{\text {new,below }}-\tau_{\text {new,above }}$ & 0.15 & 0.02 & 0.18 & 0.26 \\
& $(0.40)$ & $(0.32)$ & $(0.24)$ & $(0.20)$ \\
[i]-[ii] & 0.41 & $\mathbf{0 . 5 2}$ & 0.11 & -0.11 \\
& $(0.39)$ & $(0.24)$ & $(0.32)$ & $(0.32)$ \\
\hline
\end{tabular}

B. Abnormal Delinquencies as a Function of PSL Constraint Tightness Proxy (Equation 4) Using a Six-month Time Window Around PSL Threshold Changes

\begin{tabular}{lcccc}
$\eta$ & -0.03 & -0.02 & -0.03 & -0.04 \\
\multicolumn{7}{c}{$\begin{array}{l}\text { Using a Three-month Time Window } \\
\eta\end{array}$} & $-0.17)$ & $(0.16)$ & $(0.17)$ & $(0.16)$ \\
& $(0.17)$ & $(0.18)$ & $(0.19)$ & $(0.18)$ \\
\hline
\end{tabular}




\section{Table 6: Impact of Risk Weight Regulation on Abnormal Delinquency Rate}

This table provides parameters of interest from the combination of Equations 1 (in section A) and Equation 8 (in section B) in the paper estimated as Cox hazard models on the population of loans disbursed around a $75 \%$ loan-cost ratio around the time of risk weight changes for loans below $75 \%$ loan-to-value. In section $\mathrm{A}$, the reported values are differences in abnormal delinquency rates on loans disbursed below and above a $75 \%$ loan-cost ratio under regimes where risk weights on loans disbursed around that threshold are [i] relatively far and [ii] relatively close. In section B, the coefficient $\eta$ represents the impact of the risk weight advantage carried on less leveraged loans (100\% minus the risk weight on these loans) on abnormal delinquency rates. Coefficients and standard errors are scaled to reflect the impact relative to the average delinquency rate in the full loan sample. Standard errors (reported in parentheses) are computed by bootstrapping years of the panel data, with bold and italicized type representing statistical significance at the five and ten percent level respectively.

Using a Six-month Time Window Around Risk Weight Changes

\begin{tabular}{|c|c|c|c|}
\hline Loan/Cost Ratio Window: & $1.0 \%$ & $2.0 \%$ & $3.0 \%$ \\
\hline Observations (Above $75 \%$ Loan-Cost): & 33,673 & 78,518 & 122,524 \\
\hline Observations (At/Below 75\% Loan-Cost): & 96,634 & 130,412 & 154,537 \\
\hline \multicolumn{4}{|c|}{ Using a Three-month Time Window Around Risk Weight Changes } \\
\hline Observations (Above 75\% Loan-Cost): & 16,207 & 38,508 & 59,448 \\
\hline Observations (At/Below 75\% Loan-Cost): & 47,149 & 63,782 & 75,622 \\
\hline \multicolumn{4}{|c|}{ A. Difference-in-Difference Specification (Equation 1) } \\
\hline \multicolumn{4}{|c|}{ Using a Six-month Time Window Around Risk Weight Changes } \\
\hline \multirow[t]{2}{*}[\mathrm{i}]{$: \tau_{\text {far,below }}-\tau_{\text {far,above }}$} & 0.10 & 0.03 & -0.07 \\
\hline & $(0.06)$ & $(0.06)$ & $(0.08)$ \\
\hline \multirow[t]{2}{*}{ [ii]: $\tau_{\text {close,below }}-\tau_{\text {close,above }}$} & -0.13 & -0.12 & -0.01 \\
\hline & $(0.08)$ & $(0.07)$ & $(0.06)$ \\
\hline \multirow[t]{2}{*}{ [i]-[ii] } & 0.23 & 0.15 & -0.07 \\
\hline & $(0.09)$ & $(0.10)$ & $(0.10)$ \\
\hline \multicolumn{4}{|c|}{ Using a Three-month Time Window Around Risk Weight Changes } \\
\hline \multirow[t]{2}{*}{ [i]: $\tau_{\text {far,below }}-\tau_{\text {far,above }}$} & 0.35 & 0.22 & 0.03 \\
\hline & $(0.11)$ & $(0.09)$ & $(0.06)$ \\
\hline \multirow[t]{2}{*}{ [ii]: $\tau_{\text {close }, \text { below }}-\tau_{\text {close,above }}$} & -0.23 & -0.05 & -0.01 \\
\hline & $(0.15)$ & $(0.11)$ & $(0.09)$ \\
\hline \multirow[t]{2}{*}{ [i]-[ii] } & 0.59 & 0.26 & 0.05 \\
\hline & $(0.13)$ & $(0.13)$ & $(0.13)$ \\
\hline \multicolumn{4}{|c|}{ B. Abnormal Delinquencies as a Function of Risk Weight Advantage (Equation 8) } \\
\hline \multicolumn{4}{|c|}{ Using a Six-month Time Window Around Risk Weight Changes } \\
\hline \multirow[t]{2}{*}{$\eta$} & 0.22 & 0.10 & -0.03 \\
\hline & $(0.22)$ & $(0.19)$ & $(0.23)$ \\
\hline \multicolumn{4}{|c|}{ Using a Three-month Time Window Around Risk Weight Changes } \\
\hline \multirow[t]{2}{*}{$-2+2+2+1$} & 0.59 & 0.61 & 0.28 \\
\hline & $(0.19)$ & $(0.11)$ & $(0.11)$ \\
\hline
\end{tabular}




\section{Table 7: Probability of Transition to Later Stage of Delinquency}

This table presents the probability that initial 30 and 90 day mortgage delinquencies become 90 and 180 day mortgage delinquencies respectively within six months following the initial delinquency. This transition probability is first computed for all loans with initial delinquencies in a given month, and the probabilities shown below are the time-series average of these monthly cross-sectional estimates, where the average is taken over the indicated time periods. Standard errors are reported in parentheses below estimates and are constructed by bootstrapping from the population of monthly cross-sectional estimates from each time period indicated. All coefficients except the differences in 90 to 180 day default transition probabilities are highly statistically significant.

Probability of 30 day Probability of 90 day Delinquency Transitioning to Delinquency Transitioning to

Month Relative 90 day Delinquency 180 day Delinquency

For Initial Delinquencies Occurring:

All Months (Jan 1996-Dec 2010)

$22.7 \%$

$22.8 \%$

$(0.3 \%)$

$(0.4 \%)$

Lender Under 180day NPA Regime

$29.2 \%$

$23.5 \%$

$(0.5 \%)$

$(0.6 \%)$

Lender Under 90day NPA Regime

$16.0 \%$

$22.2 \%$

Difference

$(0.5 \%)$

(0.6\%)

$-13.3 \%$

$-1.3 \%$

(0.7\%)

(0.9\%) 


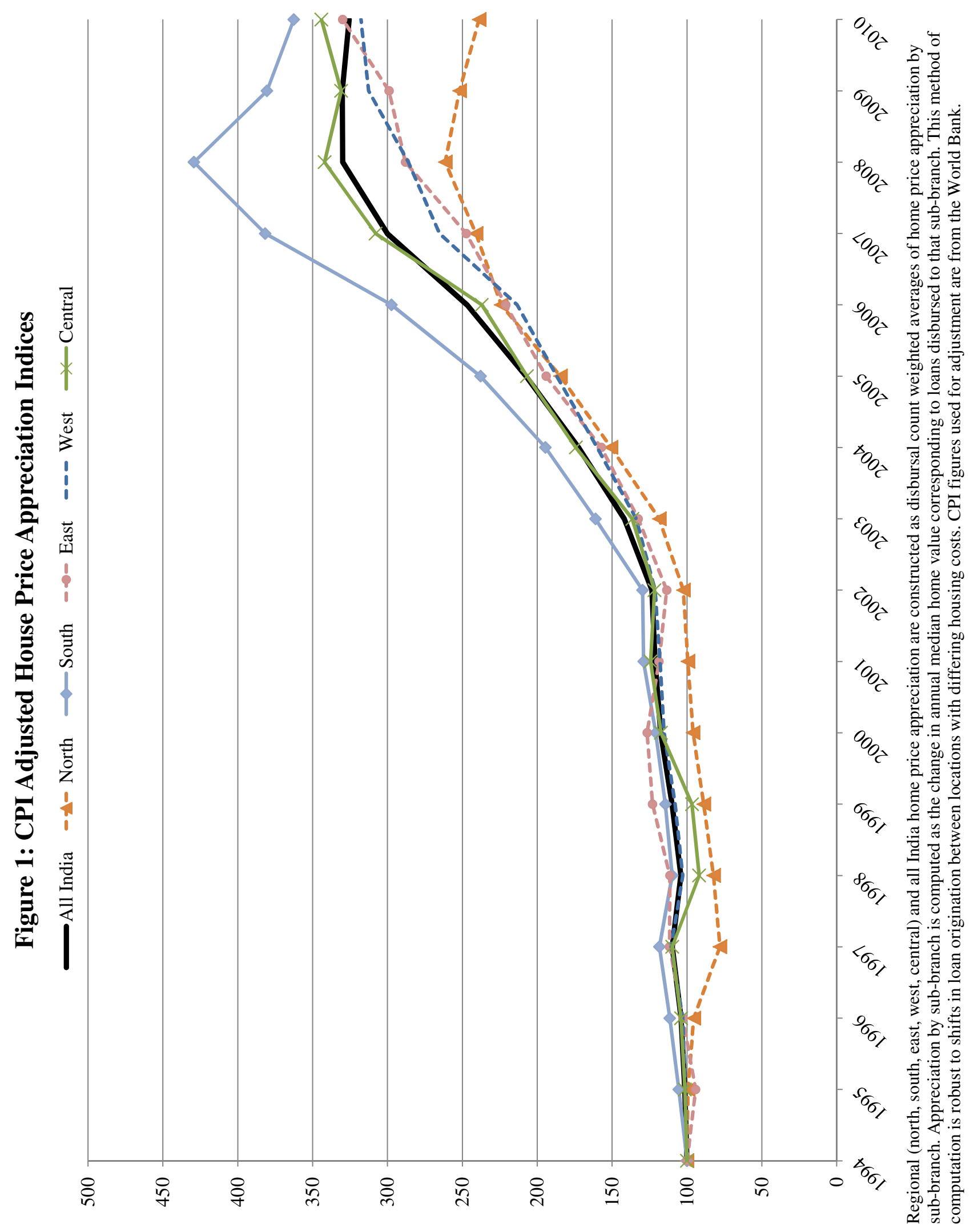




\section{Figure 2: Timeline of Indian Mortgage Regulation}

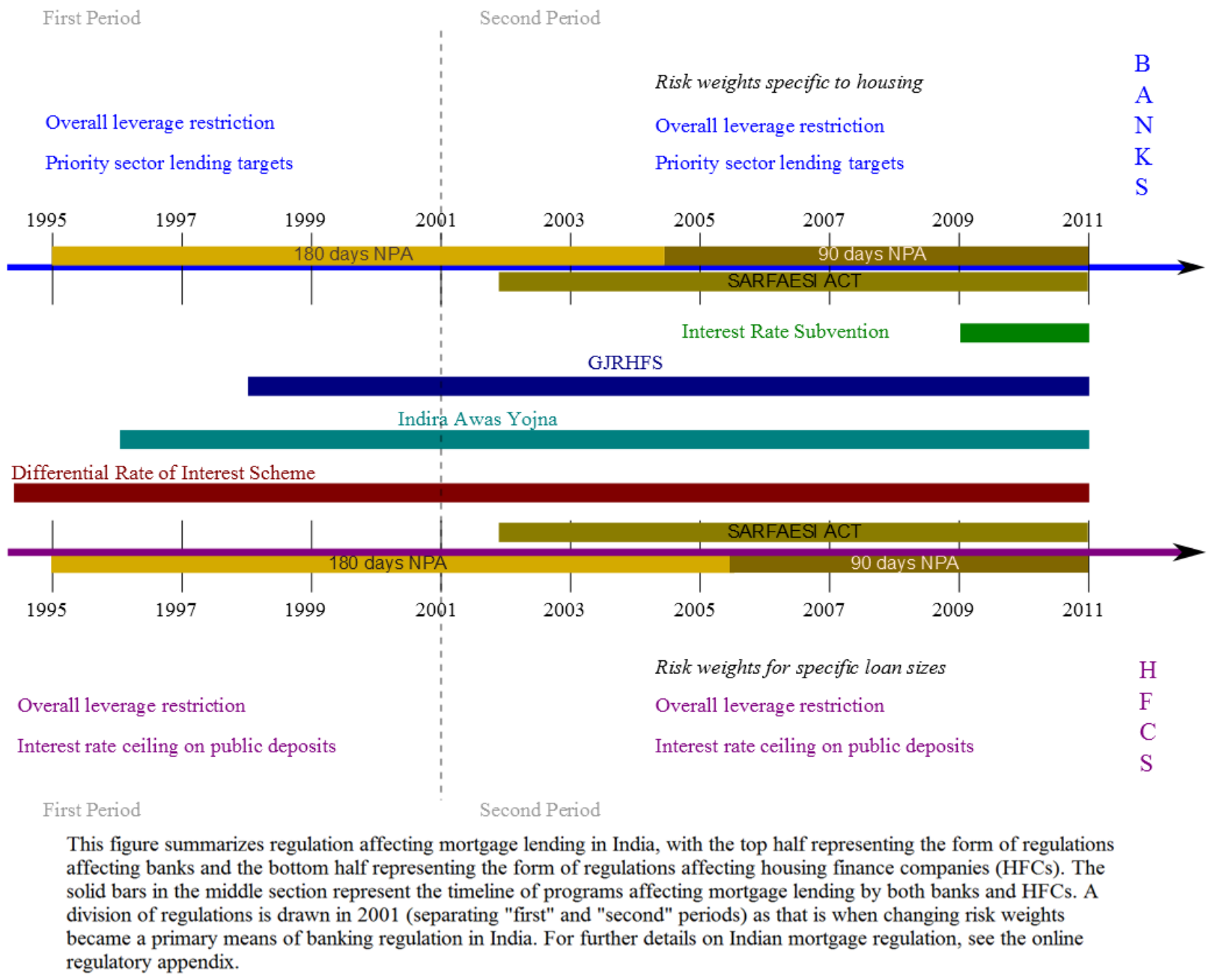




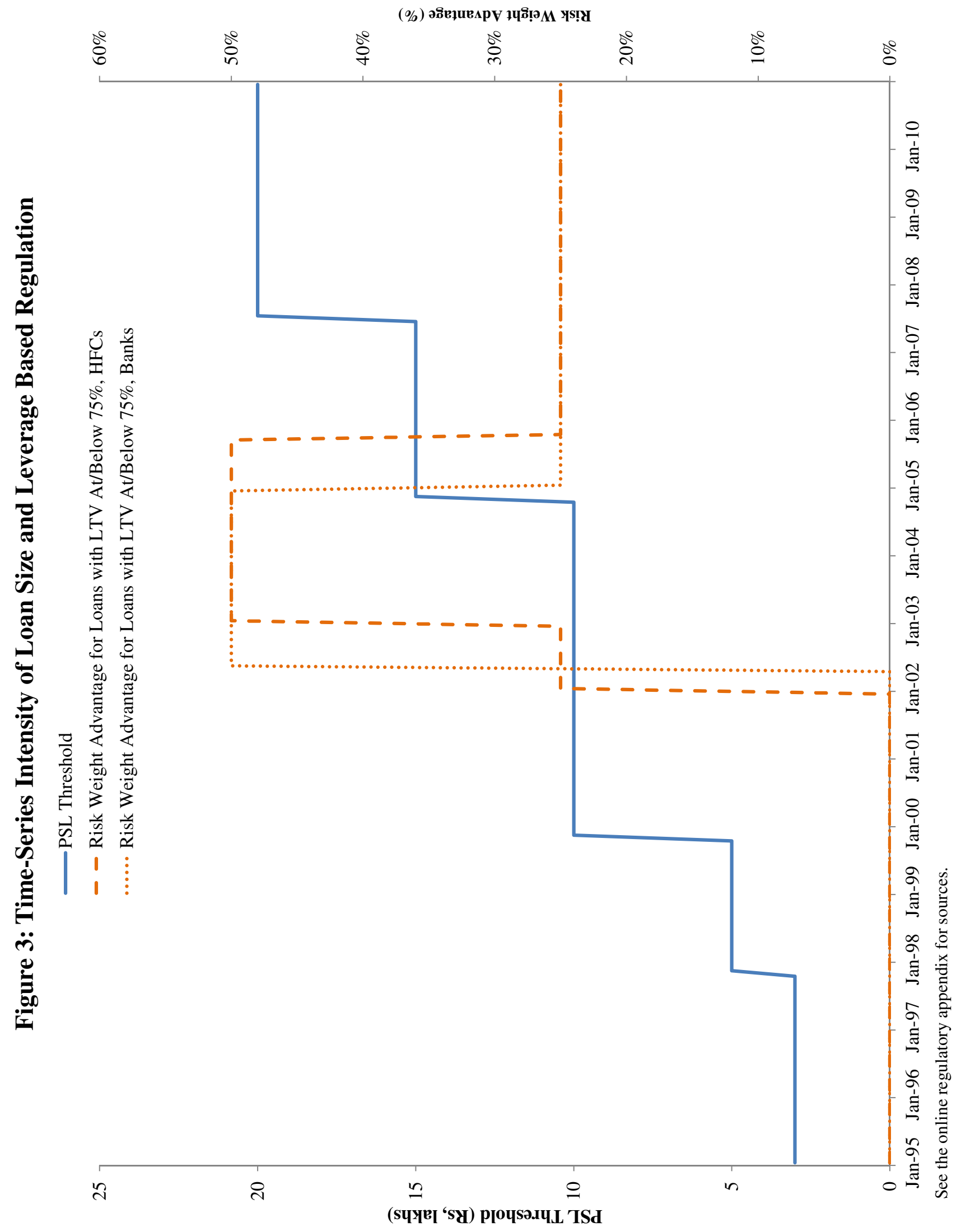




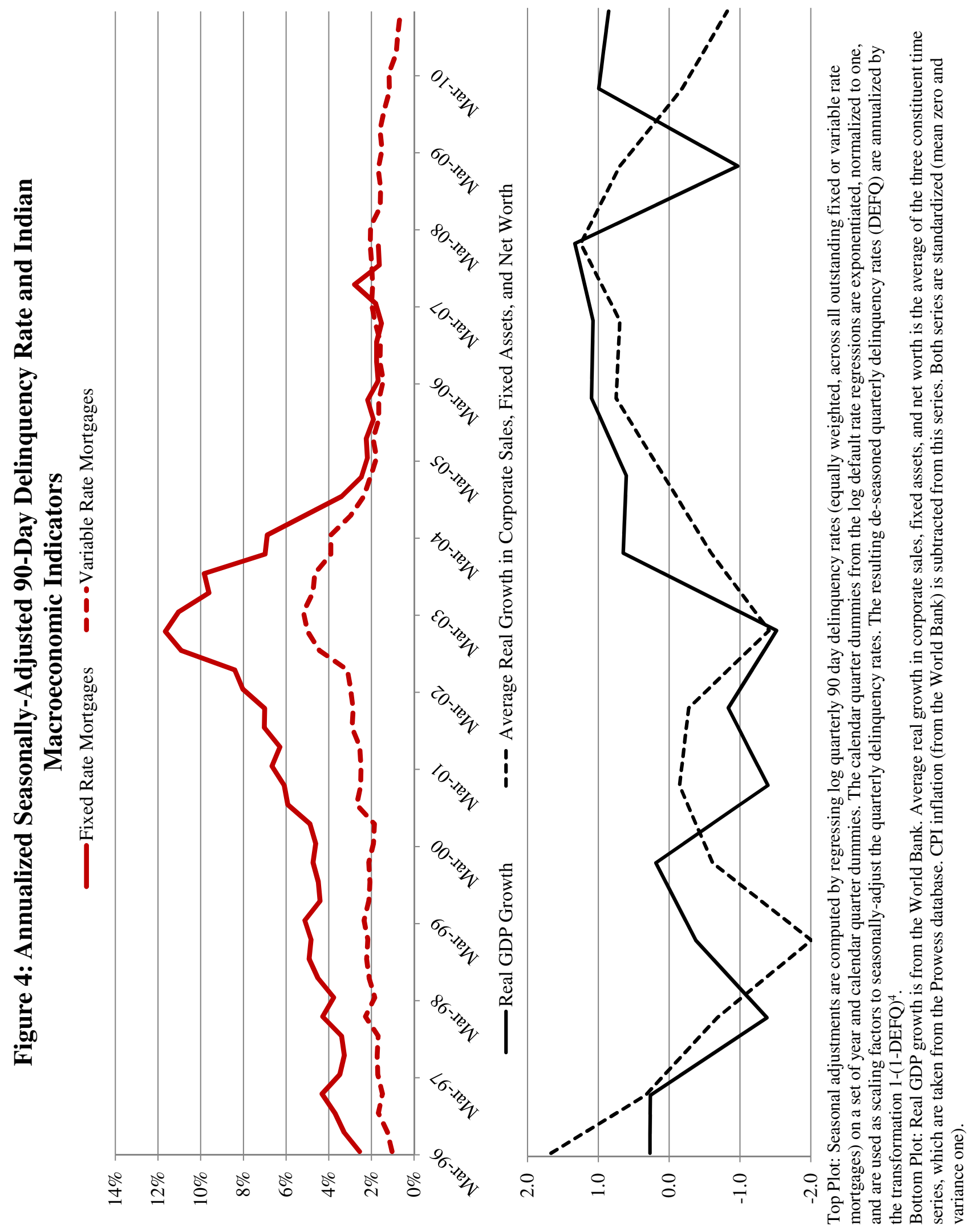




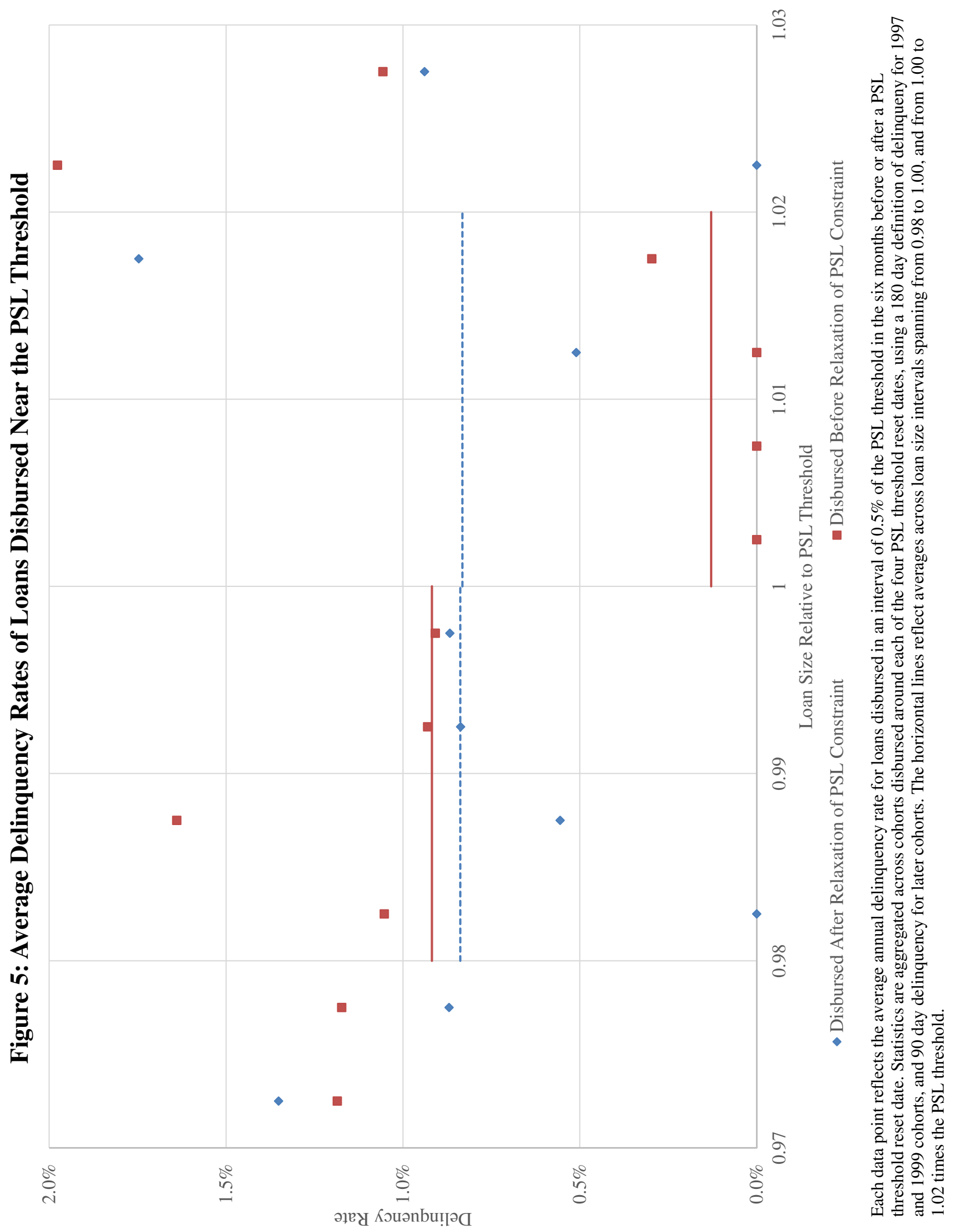

46 


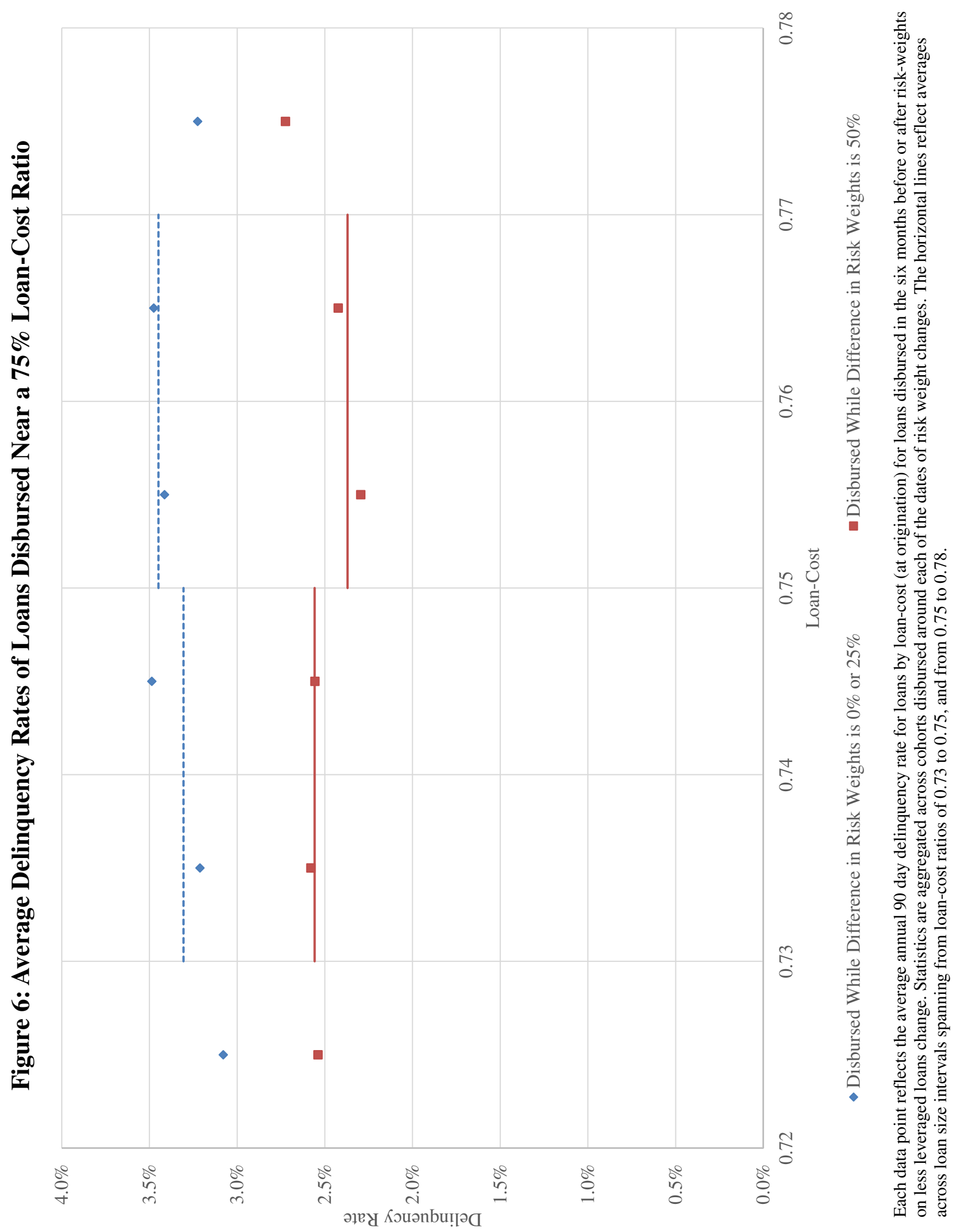

47 


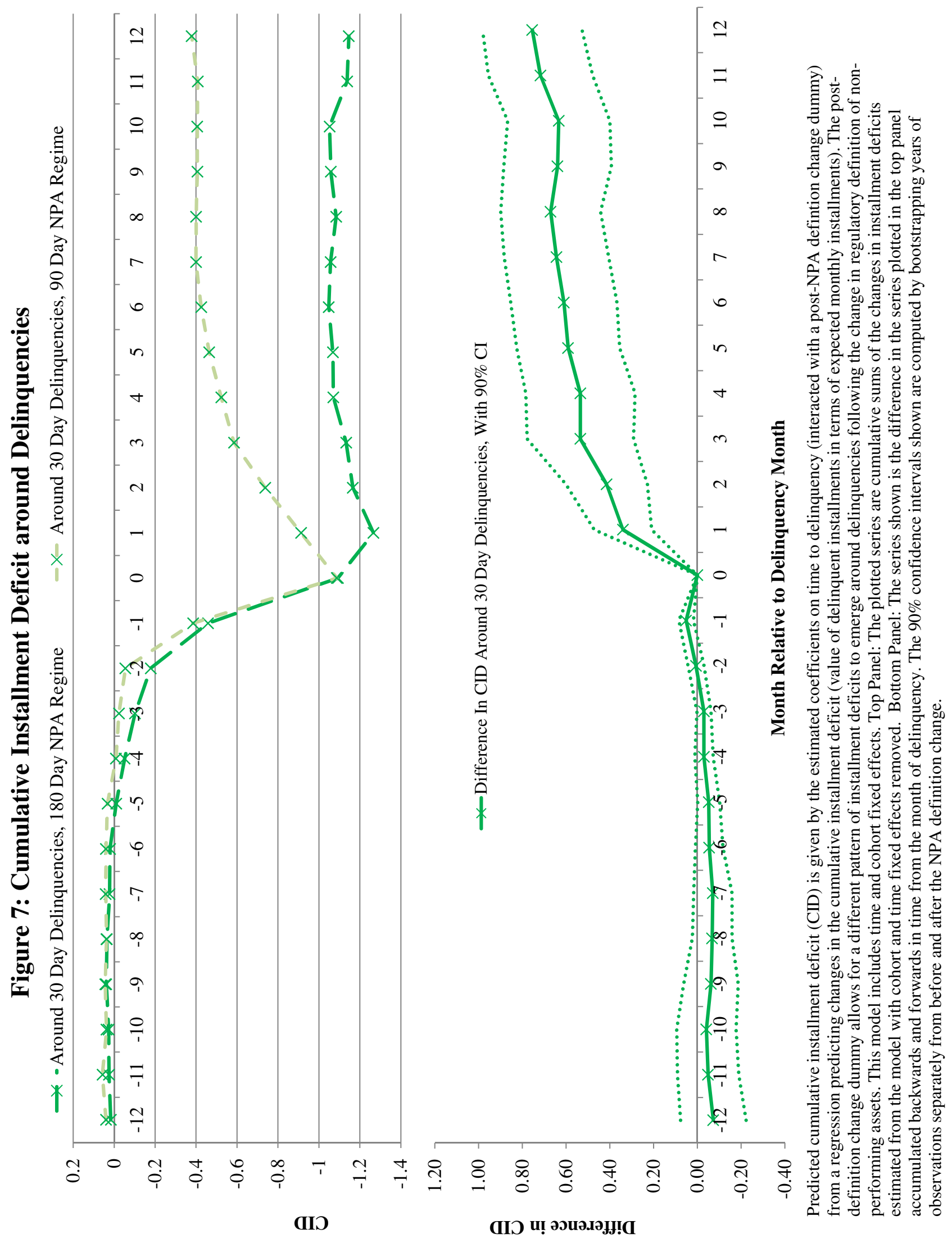




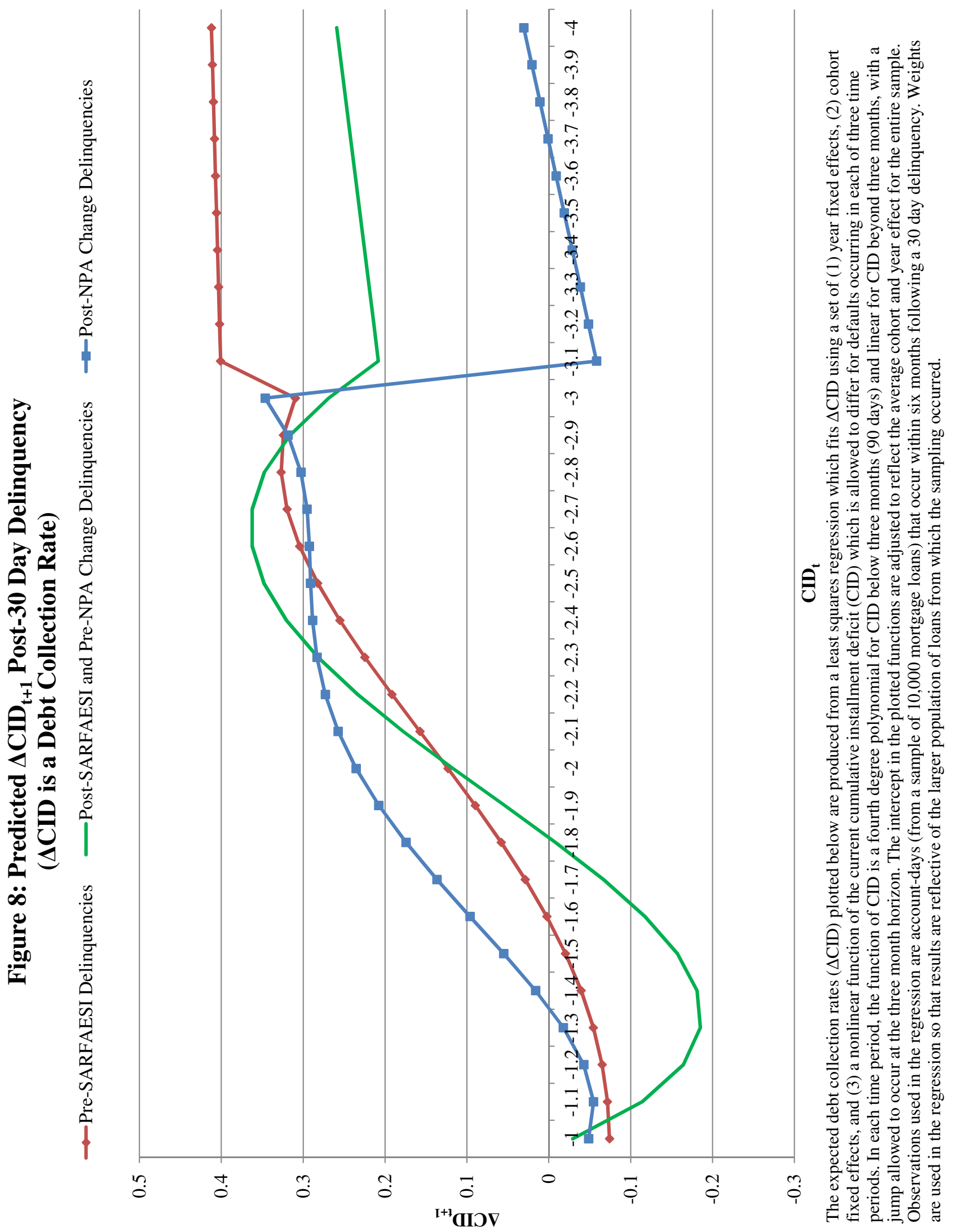




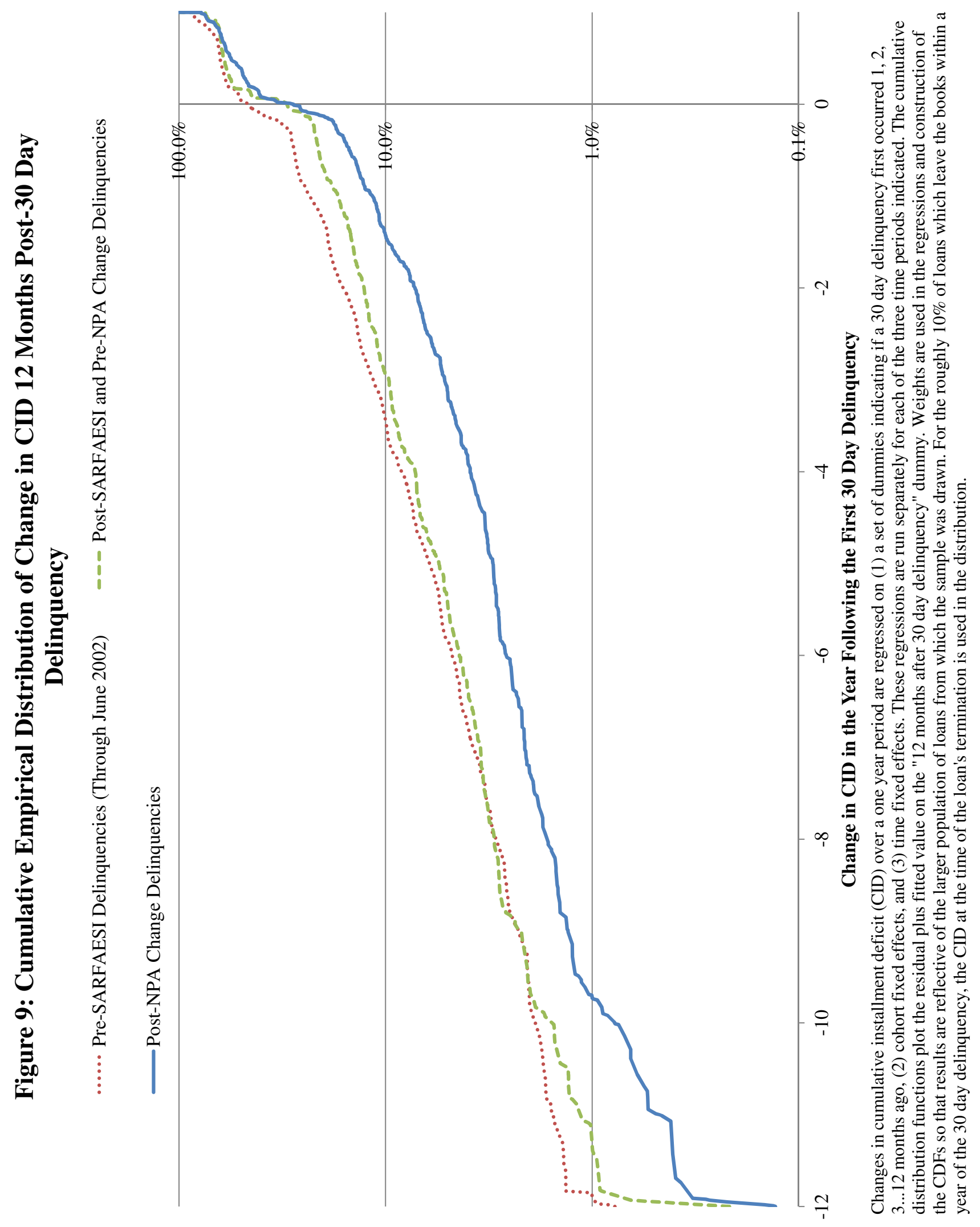




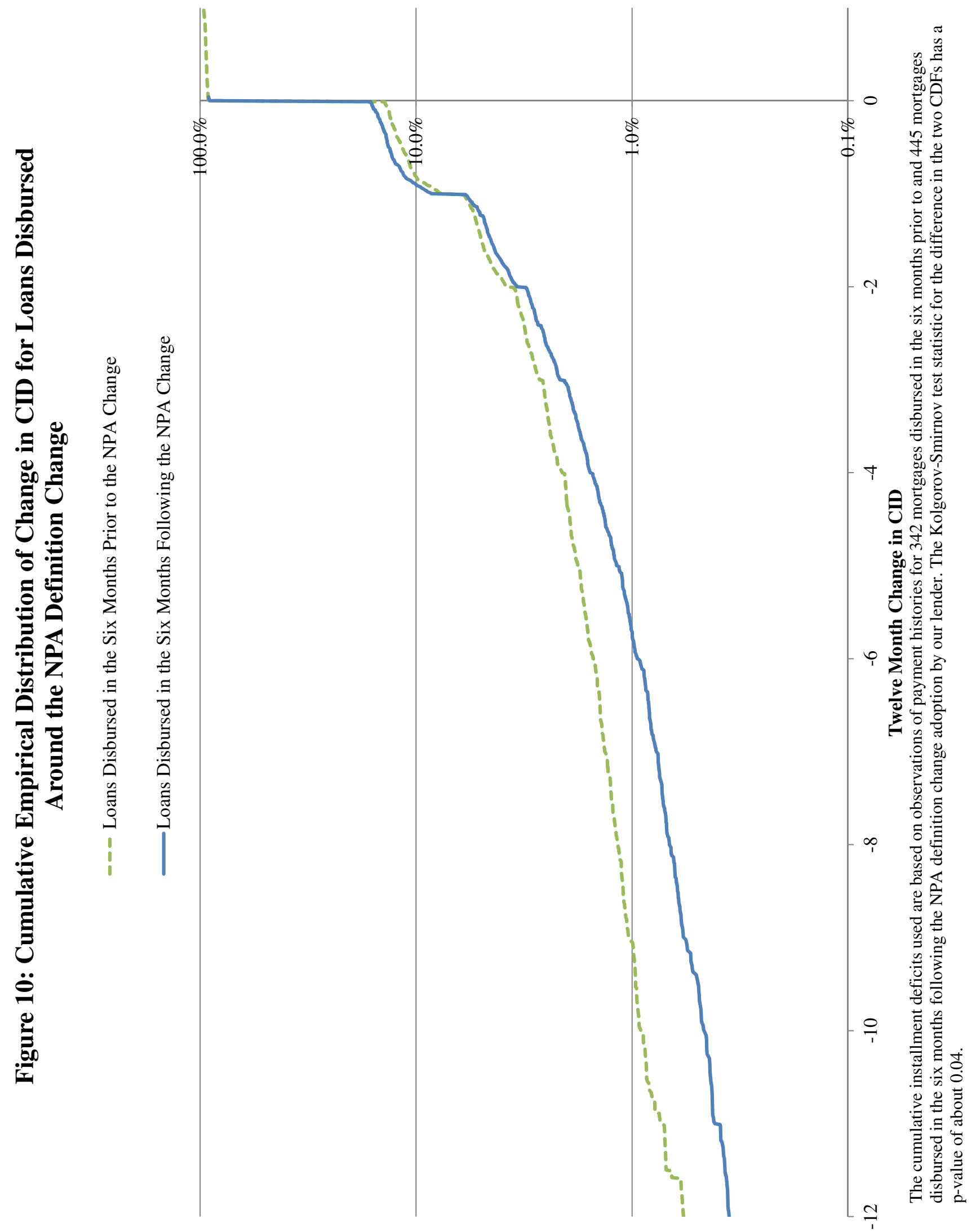

